\title{
MEREVIU BASIS PEMAJAKAN PERUSAHAAN PELAYARAN NASIONAL BERDASARKAN "DEEMED PROFIT" ATAS PENGHASILAN DARI USAHA ANGKUTAN LAUT
}

\author{
Chairil Anwar Pohan \\ Institut Ilmu Sosial dan Manajemen STIAMI \\ anwar.phn@gmail.com
}

\begin{abstract}
ABSTRAK.Semenjak DPR mengesahkan Undang-Undang No. 7 Tahun 1983 tentang Pajak Penghasilan, sebagaimana telah diubah terakhir dengan Undang-Undang No. 36 Tahun 2008 (jadi ada empat kali perubahan, yakni dengan UU No. 7/1991, kemudian No.10/1994, selanjutnya No.17/2000 dan terakhir No. 36/2008), tetapi basis pemajakan nasional dalam negeri dan perusahaan pelayaran luar negeri yang menerapkan Norma Penghitungan Khusus Penghasilan Neto (deemed profit) bagi Wajib Pajak perusahaan pelayaran tersebut dengan penerapan Pajak Penghasilan Pasal 15 (bersifat Final) tidak mengalami perubahan baik dalam Tarif dan Dasar Pengenaan Pajaknya, padahal tarif Pajak Penghasilan Badan (Pasal 17 ayat 1) telah mengalami perubahan mulai dari UU No. 7 tahun 1983 dengan tarif progressif 10\%-35\% terakhir berubah dengan tarif tunggal sebesar 25\% dalam UU No. 36 Tahun 2008. Demikian pula dengan Dasar Pengenaan Pajak yang digunakan kelihatannya sudah tidak wajar dengan Penghasilan Neto pelayaran luar negeri sebesar 6\%. Dasar Pengenaan Pajak yang mencerminkan rate of return perusahaan yang digunakan sebagai basis pemajakan pajak penghasilan perusahaan pelayaran nampaknya terlalu rendah, dibandingkan dengan tingkat keuntungan (net profit after tax) yang diperoleh perusahaan pelayaran dalam dan luar negeri. Kondisi ini tentu saja berdampak pada rendahnya penerimaan pajak dari sektor usaha pelayaran, dan selain itu aspek pemenuhan kaidah keadilan pajak juga terganggu karena bagi perusahaan pelayaran yang mengalami kerugian tetap saja bayar pajak final (PPh Pasal 15).
\end{abstract}

Kata Kunci : Norma Penghitungan Khusus Penghasilan Neto, PPh Pasal 15, Global Taxation, Perusahaan Pelayaran Nasional.

ABSTRACT. Since Legislative Assembly approved Law No. 7 of 1983 on Income Tax, as last amended by the Law No. 36 of 2008 (so there are four time changes, namely by the Law No. 7 of 1991, then No. 10 of 1994, furthermore No. 17 of 2000 and the last No. 36 of 2008), but the base of the domestic and overseas shipping company taxation which apply Special Calculation Norm of Net Income (deemed profit) for the national and overseas shipping companies taxpayers with the application of Article 15 of the Income Tax (Final Tax) did not change either in the tax rates and the tax bases, whereas the corporate tax rate (Article 17 paragraph 1) has changed from the Law No. 7 of 1983 with progressive rates levying at the rate of 10\% -35\% with the last change to a flat rate of $25 \%$ in the Law No. 36 of 2008. Similarly, the Tax Base used appear to have been unreasonable to overseas shipping Net Income amounted to 6\%. Tax Base which reflects the rate of return the company is used as a base taxation income tax shipping company seems too low, compared with the rate of profit (net profit after tax) obtained by shipping companies at home and abroad. These conditions certainly result in low tax revenue from the shipping sector, and on the other aspects of the fulfillment of tax fairness rules also disrupted due to the shipping company suffered a loss nonetheless pay a final tax (VAT Article 15).

Keywords : Special Calculation Norm of Net Income, PPh Article 15, Global Taxation, National Shipping Companies 


\section{Chairil Anwar Pohan, Mereviu Basis Pemajakan Perusahaan Pelayaran....}

\section{PENDAHULUAN}

\section{LATAR BELAKANG}

Sejak Indonesia 1962 menjadi bagian dari organisasi Negara pengekspor minyak dunia yang dikenal sebagai OPEC (Organization of Petroleum Exporting Country), puncak dari keberhasilan eksplorasi minyak dan gas terjadi pada tahun 1977, dimana pada tahun tersebut Indonesia mampu mencapai produksi minyak mentah hingga 1,6 juta barel per hari, sehingga berdasarkan rilis kementrian keuangan, 75\% penerimaan Negara pada periode 1970an berasal dari sektor minyak dan gas. Tingginya penerimaan Negara akibat ekspor minyak mentah menyebabkan era tersebut dikenal sebagai era bonanza minyak.

Sejak berakhirnya bonanza penerimaan minyak dan gas bumi (migas) yang mendominasi penerimaan negara untuk pembiayaan pembangunan sekitar tahun 1991 dan 1992 (Berdasarkan Nota Keuangan dan APBN Tahun 2001, tingkat produksi minyak mentah Indonesia merupakan angka yang didasarkan pada kuota OPEC dan kapasitas tingkat produksi minyak Indonesia. Dalam tahun 2002 tingkat produksi minyak mentah Indonesia diperkirakan sekitar 1,32 juta barel per hari, atau sama dengan produksi tahun 2001, berarti terdapat penurunan dibandingkan dengan tahun 1977), maka sejak saat itu pula era keemasan migas digantikan dengan pajak dan dari sektor non migas lainnya seperti terlihat dalam APBN tahun 1991/1992 yang merekam peristiwa tersebut. Ketika itu migas sebagai non-renewable resources disadari akan habis karena terus dieksploitasi secara besar-besaran oleh pemerintah maupun para pengusaha swasta.

Oleh karena itu, alternatif lain untuk meningkatkan sumber penerimaan yang dirasakan paling memungkinkan dan aman serta dapat diandalkan adalah penerimaan dari sektor non migas, termasuk penerimaan-penerimaan dari sektor pajak. Sejak tahun 1945 harapan tersebut sebenarnya sudah terantisipasi dalam Pasal 23A Undang-Undang Dasar 1945 (sebagaimana telah diubah dengan perubahan keempat tahun 2002) yang berbunyi "Pajak dan pungutan lain yang bersifat memaksa untuk keperluan negara diatur dengan undang-undang".
Penerimaan pajak yang diperoleh pemerintah merupakan penjabaran pelaksanaan fungsi pajak yakni fungsi budgeter, ini berarti bahwa pemerintah khususnya Direktorat Jenderal Pajak sebagai instansi yang menangani hal-hal yang berkaitan dengan perpajakan, harus mampu menciptakan dan mengimplementasikan sistem perpajakan yang dapat mendukung penerimaan pajak, sehingga dapat memenuhi dana yang dibutuhkan untuk membiayai kegiatan-kegiatan pemerintah dalam penyelenggaraan Negara untuk pembangunan nasional, dan meningkatkan kesejahteraan masyarakat. Kinerja perpajakan kita masih relatif tertinggal dibandingkan dengan Negara lain juga dilihat dari sisi tax ratio dan indikator-indikator perpajakan lainnya. Pemerintah menyadari bahwa sumber penerimaan dalam negeri yang paling handal dan aman adalah yang bersumber dari penerimaan pajak, namun faktanya tax ratio kita masih rendah (di sekitar 12\%), sedangkan penerimaan dari sumber daya alam lainnya belum memadai untuk menjadi penyangga pembiayaan pembangunan. Rendahnya tingkat kesadaran dan kepatuhan wajib pajak ini membuat tax ratio kita relatif masih rendah di Asean (Asri Harahap, 2004:vii).

Sudah berjalan 31 tahun semenjak diberlakukannya UU Pajak Penghasilan No. 7 tahun 1983 sebagaimana telah diubah terakhir dengan UU No. 36 Tahun 2008, suatu perjalanan waktu yang cukup panjang dalam pembelanjaran (learning curve) fiskus dalam hal penerapan pajak berbasiskan penghasilan (Income Based Tax) pada perusahaan pelayaran (shipping companies) untuk angkutan interinsulair maupun angkutan luar negeri. Perusahaan pelayaran merupakan wajib pajak yang dalam pemenuhan kewajiban perpajakan untuk menghitung pajak penghasilan badan terutang tunduk pada Pasal 15 UU PPh yang mana Pasal 15 ini menegaskan bahwa Menteri Keuangan dapat mengeluarkan keputusan untuk menetapkan Norma Penghitungan Khusus guna menghitung penghasilan netto dari Wajib Pajak tertentu yang tidak dapat dihitung berdasarkan Pasal 16. Selanjutnya Pasal 16 menyatakan 


\section{TRANSPARANSI}

Jurnal Ilmiah Ilmu Administrasi

ISSN 2085-1162

bahwa : “(1) Penghasilan kena pajak, sebagai dasar penerapan tarif bagi Wajib Pajak dalam negeri dalam suatu tahun pajak, dihitung dengan cara mengurangkan penghasilan sebagaimana dimaksud dalam Pasal 4 ayat(1), dengan pengurangan sebagaimana dimaksud dalam Pasal 6 ayat(1), Pasal 7 ayat(1), dan Pasal 9 ayat(1) huruf b, huruf c, dan huruf d. (2) Penghasilan kena pajak bagi Wajib Pajak dalam negeri tertentu sebagaimana dimaksud dalam Pasal 14 ayat(2), dihitung dengan menggunakan Norma Penghitungan sebagaimana dimaksud dalam Pasal 14 ayat(1). (3) Penghasilan kena pajak bagi Wajib Pajak luar negeri adalah jumlah penghasilan bruto yang diterima atau diperoleh."

Menggunakan Pasal 15 tersebut sebagai dasar untuk pengenaan pajak, bisa mendatangkan kerugian/kekurangan bagi pemasukan negara, karena mekanisme $\mathrm{PPh}$ terganggu akibat secara theoritical global taxation consept dari tax base-nya tidak terbidik secara efektif. Konsep yang berbasiskan Norma Penghitungan khusus yang selanjutnya disebut Norma Penghitungan Penghasilan Neto yang ditawarkan untuk menangkap adanya objek PPh yang terkandung dalam pendapatan wajib pajak perusahaan pelayaran termasuk uang tambang (freight) sebagai pendapatan negara, dengan dasar pertimbangan untuk memberikan kepastian hukum, kesederhanaan dan kemudahan bagi wajib pajak tersebut dalam menghitung pajak penghasilan badan yang terutang, namun dari sudut pandang Azas Kecukupan Penerimaan (The Revenue Adequacy Principle) konsep tersebut bisa menimbulkan permasalahan bagi kekurangan penerimaan Negara karena adanya perbedaan dalam perhitungan $\mathrm{PPh}$ Pasal 15 Final dengan $\mathrm{PPh}$ badan yang terutang yang berbasiskan global taxation sebagaimana dimaksud dalam Pasal 4 ayat(1) UU PPh dimana pendapatan perusahaan pelayaran dapat dijaring dari pembukuan/accounting komersial yang diselenggarakan berbasiskan Standard Akuntansi Keuangan yang berlaku.
Peneliti juga menangkap persoalan selain yang diterakan diatas dilihat dari dimensi keadilan pajak (equality), sementara perusahaan-perusahaan pelayaran khususnya sebahagian besar perusahaan-perusahaan terbuka (Tbk) yang telah menikmati pajak korporasi yang rendah, namun beberapa entitas yang mengalami kerugian malah terbebani dengan PPh Pasal 15 Final dan tidak bisa mengkompensaskannya ke masa pajak berikutnya. Ibarat pribahasa yang mengatakan "sudah jatuh tertimpa tangga".

Tidak saja perusahaan pelayaran nasional yang disasar, tetapi fenomena ini juga membidik Perusahaan pelayaran asing yakni perusahaan pelayaran yang tidak didirikan atau tidak bertempat kedudukan di Indonesia dan memperoleh penghasilan (business profit dan passive income) dari Indonesia khususnya Bentuk Usaha Tetap (BUT) karena perusahaan pelayaran asing yang melakukan kegiatan usaha angkutan laut di Indonesia harus menunjuk agen di dalam negeri, yaitu perusahaan pelayaran dalam negeri untuk mewakili kepentingannya dalam melakukan kegiatan di Indonesia.

\section{Fokus Penelitian}

Penelitian ini akan difokuskan pada pemajakan atas angkutan laut dalam negeri dan luar negeri pada perusahaan pelayaran nasional di Indonesia pasca berlakunya Keputusan Menteri Keuangan No. 416/KMK.04/1996 dan Surat Edaran Dirjen Pajak No. SE-35/PJ.4/1996 Tanggal 29 Agustus 1996 tentang Norma Penghitungan Khusus Penghasilan Neto bagi Wajib Pajak yang bergerak di bidang usaha Pelayaran dan/atau Penerbangan Dalam Negeri, dan Keputusan Menteri Keuangan No. 417/KMK.04/1996 dan Surat Edaran Dirjen Pajak No. SE-32/PJ.4/1996 Tanggal 29 Agustus 1996 tentang Norma Penghitungan Khusus Penghasilan Neto bagi Wajib Pajak yang bergerak di bidang usaha Pelayaran dan/atau Penerbangan Luar Negeri. 
Dalam penelitian ini, karena ruang lingkup perusahaan pelayaran tersebut cukup luas meliputi perusahaan pelayaran nasional/domestik dan perusahaan pelayaran asing (BUT) ditambah lagi dengan adanya keterbatasan data yang didapatkan, serta untuk menjaga ketajaman dalam analisa pembahasan agar hasil penelitian tidak bias, maka peneliti membatasi tidak mengupas masalah pemajakan pajak penghasilan atas perusahaan pelayaran asing yang memiliki Bentuk Usaha Tetap di Indonesia.

Untuk singkatan penulisan Undangundang Pajak Penghasilan No. 7 Tahun 1983 sebagaimana telah diubah terakhir dengan Undang-undang No. 36 Tahun 2008, maka untuk selanjutnya dalam penulisan hasil penelitian ini disebut dengan UU PPh 1984.

\section{TINJAUAN PUSTAKA}

\section{Deemed Profit}

Istilah Deemed Profit yang menyangkut Pajak Penghasilan terdapat dalam Pasal 4 ayat (3) huruf d UU PPh 1984 yang menyebutkan “...... Wajib Pajak yang dikenakan pajak secara final atau Wajib Pajak yang menggunakan norma penghitungan khusus (Deemed Profit) sebagaimana dimaksud dalam Pasal 15".

Sedangkan Pasal 15 UU PPh 1984 menyatakan "Menteri Keuangan dapat mengeluarkan keputusan untuk menetapkan Norma Penghitungan Khusus guna menghitung penghasilan netto dari Wajib Pajak tertentu yang tidak dapat dihitung berdasarkan Pasal 16". Dalam penjelasan pasal ini menegaskan bahwa ketentuan dalam Pasal ini mengatur tentang Norma Penghitungan Khusus untuk golongangolongan Wajib Pajak tertentu berdasarkan Keputusan Menteri Keuangan. Dalam praktek sering dijumpai kesukaran dalam menghitung besarnya penghasilan dan penghasilan kena pajak bagi golongan Wajib Pajak tertentu, sehingga berdasarkan pertimbangan praktis, oleh undang-undang ini, Menteri Keuangan diberi wewenang untuk mengeluarkan Keputusan untuk menentukan Norma Penghitungan Khusus guna menghitung besarnya penghasilan netto, yang dengan sendirinya akan menjadi dasar penghitungan penghasilan kena pajak bagi golongan Wajib Pajak tertentu tersebut. Sementara itu, Pasal 16 menyatakan sebagai berikut : (1) Penghasilan kena pajak, sebagai dasar penerapan tarif bagi Wajib Pajak dalam negeri dalam suatu tahun pajak, dihitung dengan cara mengurangkan penghasilan sebagaimana dimaksud dalam Pasal 4 ayat (1), dengan pengurangan sebagaimana dimaksud dalam Pasal 6 ayat (1), Pasal 7 ayat (1), dan Pasal 9 ayat (1) huruf b, huruf c, dan huruf d. (2) Penghasilan kena pajak bagi Wajib Pajak dalam negeri tertentu sebagaimana dimaksud dalam Pasal 14 ayat (2), dihitung dengan menggunakan Norma Penghitungan sebagaimana dimaksud dalam Pasal 14 ayat (1). (3) Penghasilan kena pajak bagi Wajib Pajak luar negeri adalah jumlah penghasilan bruto yang diterima atau diperoleh. (Faisal, 2009:450)

\section{PPh Final}

Pada umumnya, perlakuan atas PPh yang bersifat final tercermin pada tiga karakteristik yang melekat padanya, yakni : (Disadur dari Tansuria, 2011:76)

a. Untuk memberikan kepastian hukum, kesederhanaan dan kemudahan bagi wajib pajak yang diterima atau diperoleh orang pribadi atau badan dikenakan Pajak Penghasilan yang bersifat final. (PP No. 41 Tahun 1994)

b. Penghasilan tersebut tidak perlu digabung dengan penghasilan lainnya dalam penghitungan Pajak Penghasilan yang terutang dalam pengisian Surat Pemberitahuan Tahunan Pajak Penghasilan. (Pasal 1 ayat(1) PP No. 41 Tahun 1994)

Dalam menghitung Penghasilan Kena Pajak yang dikenai tarif umum Pasal 17 UU PPh, tidak boleh digabungkan dengan penghasilan yang telah dikenai pajak dengan tarif yang bersifat final. Biaya-biaya yang berkenaan dengan 
TRANSPARANSI

Jurnal Ilmiah Ilmu Administrasi

ISSN 2085-1162

penghasilan yang dikenakan pemotongan, pemungutan, atau pembayaran $\mathrm{PPh}$ yang bersifat final tidak boleh dikurangkan dari penghasilan bruto yang pengenaan pajaknya dilakukan berdasarkan tarif umum. (Surat Edaran Dirjen Pajak No. 97/PJ/2011butir 5a)

c. Demikian pula Pajak Penghasilan yang telah dipotong tidak dapat dikreditkan dengan Pajak Penghasilan yang terutang menurut Surat Pemberitahuan Tahunan Pajak Penghasilan. (Pasal 1 ayat(1) PP No. 41 Tahun 1994)

\section{Kapal Laut dan Perusahaan Pelayaran}

Pasal 310 ayat (1) KUHD berbunyi :'Kapal laut adalah semua kapal yang dipakai untuk pelayaran di laut atau yang diperuntukkan untuk itu". Istilah kapal laut terdiri dari dua kata, yaitu "kapal" dan "laut" . Yang dimaksud dengan "kapal" ialah semua jenis kapal, misalnya kapal niaga, kapal nelayan laut, kapal pesiar, kapal penolong (reddingsboten), kapal pengeruk lumpur, kapal tunda dan lain-lainnya. Adapun istilah "laut"adalah lawan dari istilah "perairan darat" atau "perairan pedalaman" . Yang dimaksud dengan "Perairan darat" ialah : sungai, terusan (kanal), danau, perairan pantai dibelakang rambu laut dan perairan dalam lingkungan tembok pelabuhan. (Purwosutjipto, 1989:16)

Menurut Kosasih dan Soewedo (2012:11), "Perusahaan Pelayaran (shipping company) adalah perusahaan yang mengoperasikan kapal untuk mencari pendapatan berupa uang tambang".

Martono dan Tjahjono(2011:7) mengutip beberapa pengertian yang terkait dengan Undang-undang Pelayaran No. 17 tahun 2008 maupun yang diatur pada tataran peraturan pemerintah maupun peraturan Menteri Perhubungan, sebagai berikut :

1. Agen Umum adalah perusahaan angkutan laut nasional atau perusahaan nasional yang khusus didirikan untuk melakukan usaha keagenan kapal, yang ditunjuk oleh perusahaan angkutan laut asing untuk mengurus kepentingan kapalnya selama berada di Indonesia.

2. Angkutan laut dalam negeri adalah kegiatan angkutan laut yang dilakukan di wilayah perairan laut Indonesia yang diselenggarakan oleh perusahaan angkutan laut.

3. Angkutan laut luar negeri adalah kegiatan angkutan laut dari pelabuhan Indonesia ke pelabuhan luar negeri atau dari pelabuhan luar negeri ke pelabuhan Indonesia yang diselenggarakan oleh perusahaan angkutan laut.

4. Angkutan laut pelayaran rakyat adalah usaha rakyat yang bersifat tradisional dan mempunyai karakteristik tersendiri untuk melaksanakan angkutan di perairan dengan menggunakan kapal layar, kapal layar bermotor, dan/atau kapal motor sederhana berbendera Indonesia dengan ukuran tertentu. (Pasal 1 angka 5 UU No. 17/2008)

5. Kapal adalah kendaraan air dengan bentuk dan jenis tertentu, yang digerakkan dengan tenaga angin, tenaga mekanik, energi lainnya, ditarik atau ditunda, termasuk kendaraan yang berdaya dukung dinamis, kenderaan dibawah permukaan air serta alat apung dan bangunan terapung yang tidak berpindah-pindah.

6. Angkutan di Perairan adalah kegiatan mengangkut dan/atau memindahkan penumpang dan/atau barang dengan menggunakan kenderaan air dengan bentuk dan jenis tertentu yang digerakkan dengan tenaga angin, tenaga mekanik, energi lainnya, ditarik atau ditunda atau dihela, termasuk kendaraan yang berdaya dukung dinamis, kenderaan dibawah permukaan air serta alat apung dan bangunan terapung yang tidak berpindah-pindah.

\section{Wajib Pajak Perusahaan Pelayaran}


Wajib Pajak Perusahaan Pelayaran Dalam Negeri adalah orang yang bertempat tinggal atau badan yang didirikan dan berkedudukan di Indonesia yang melakukan usaha pelayaran dengan kapal yang didaftarkan baik di Indonesia maupun di luar negeri atau dengan kapal pihak lain. (Barata\&Jajat, 2004: 205)

Wajib Pajak Perusahaan Pelayaran/Penerbangan Luar Negeri adalah Wajib Pajak perusahaan pelayaran dan atau penerbangan yang bertempat kedudukan di luar negeri yang melakukan usaha melalui Bentuk Usaha Tetap di Indonesia (Barata\&Jajat, 2004: 200)

\section{Jenis Pendapatan Usaha Pelayaran}

Beberapa jenis pendapatan pada usaha pelayaran menurut Kosasih dan Soewedo (2012:251) adalah sebagai berikut :

a. Pendapatan freight atau uang tambang adalah balas jasa angkutan laut untuk menyampaikan muatan/barang dari pelabuhan muat sampai dengan pelabuhan tujuan. Ada freight prepaid atau freight yang dibayar di pelabuhan muat, dan ada freight collect atau freight yang dibayar di pelabuhan tujuan (atas beban importir).

b. Pendapatan carter adalah hasil mencarterkan kapal milik, biasanya tarifnya harian (charter rate day).

c. Pendapatan B/L Commission adalah komisi dari operasi underwing. Sebagai contoh, di suatu pelabuhan, agen/cabang kita berhasil meraih muatan, tetapi waktu itu tidak ada kapal kita dan ada kapal lain yang mau bekerja sama mengangkut muatan tersebut dengan menggunakan $\mathrm{B} / \mathrm{L}$ perusahaan kita. Untuk itu, perusahaan kita memperoleh komisi yang berupa persentase dari net freight. d. Pendapatan komisi keagenan adalah komisi yang diterima karena bertindak sebagai agen dari principal dalam melayani kapalnya, menangani canvassing dan handling muatannya, meng-collect freight-nya, dan sebagainya.

e. Pendapatan usaha cabang untuk pengurusan dokumen perkapalan, yaitu $\mathrm{B} / \mathrm{L}$ dan penanganan EMKL, pengangkutan (haulage) container, trucking muatan, depot container, transhipment, sub-agency, dan lainlain.

\section{Kegiatan Perusahaan Pelayaran}

Menurut Kosasih dan Soewedo (2012:11), kegiatan perusahaan pelayaran terbagi atas :

1. Usaha jasa angkutan laut
a. Liner
b. Tramper
c. Feeder

2. Keagenan
a. Kapal (husbanding)
b. Muatan (canvassing)

3. Charter/sewa kapal
a. Time charter
b. Voyage charter
c. Demise (bareboat charter)

4. Jasa lainnya

\section{Tarif dan Dasar Pengenaan Pajak Perusahaan Pelayaran Dasar Hukum}

Penghasilan yang diterima wajib pajak di bidang usaha pelayaran dalam negeri dikenakan PPh yang bersifat final berdasarkan ketentuan Pasal 15 UU Pajak Penghasilan. Dasar hukum lainnya adalah: KMK416/KMK.04/1996 tentang Norma Penghitungan Khusus Penghasilan Neto bagi Wajib Pajak Perusahaan Pelayaran Dalam Negeri; Surat Edaran Direktur Jenderal Pajak Nomor SE29/PJ.4/19961996 tentang PPh terhadap Pajak Perusahaan Pelayaran 
TRANSPARANSI

Jurnal Ilmiah Ilmu Administrasi

ISSN 2085-1162

Dalam Negeri (Seri PPh Umum No. 35); SE-28/PJ.43/1998, tentang $\mathrm{PPh}$ Pasal 22 atas impor barang untuk kegiatan/jasa yang atas imbalannya semata-mata dikenakan PPh Final; dan SE-32/PJ.43/1998, tentang penegasan atas SE-28/PJ.43/1998.(Tansuria, 2011:76) .

Penghasilan yang diterima wajib pajak perusahaan pelayaran atau penerbangan luar negeri dikenakan $\mathrm{PPh}$ yang bersifat final berdasarkan ketentuan Pasal 15 UU Pajak Penghasilan. Dasar hukum lainnya adalah KMK-417/KMK.04/1996 tentang Norma Penghitungan Khusus Penghasilan Neto bagi Wajib Pajak perusahaan pelayaran dan/atau penerbangan luar negeri, serta SE32/PJ.4/1996, tentang Norma Penghitungan Khusus Penghasilan Neto bagi Wajib Pajak yang bergerak di bidang usaha pelayaran dan/atau penerbangan luar negeri (Seri $\mathrm{PPh}$ Umum No. 37) (Tansuria, 2011:81)

$\begin{array}{rrr}\text { Sesuai dengan Keputusan } \\ \text { Menteri } & \text { Keuangan } & \text { Nomor }\end{array}$ 416/KMK.04/1996 tanggal 14 Juni 1996 tentang Norma Penghitungan Khusus Penghasilan Neto bagi Wajib Pajak Perusahaan Pelayaran Dalam Negeri jo. Surat Edaran Direktur Jenderal Pajak Nomor SE-29/PJ.4/1996 tanggal 13 Agustus 1996 tentang PPh terhadap Pajak Perusahaan Pelayaran Dalam Negeri, antara lain diatur bahwa:

a. Wajib Pajak perusahaan pelayaran dalam negeri dikenakan Pajak Penghasilan atas seluruh penghasilan yang diterima atau diperolehnya baik dari Indonesia maupun dari luar Indonesia. Oleh karena itu penghasilan yang menjadi objek pengenaan $\mathrm{PPh}$ meliputi penghasilan yang diterima atau diperoleh Wajib Pajak dari pengangkutan orang dan/atau barang, termasuk penghasilan penyewaan (charter) kapal yang dilakukan dari:

- Pelabuhan di Indonesia ke pelabuhan lainnya di Indonesia;

- Pelabuhan di Indonesia ke pelabuhan di luar Indonesia;

- Pelabuhan di luar Indonesia ke Pelabuhan di Indonesia;

- Pelabuhan di luar Indonesia ke pelabuhan lainnya di luar Indonesia.

b. Penghasilan neto dari perusahaan pelayaran dalam negeri dihitung dengan menggunakan Norma penghitungan khusus yaitu sebesar 4\% (empat persen) dari peredaran bruto. Besarnya PPh yang terutang yang bersifat final adalah $1,2 \%$ (satu koma dua persen) dari peredaran bruto. (Disadur dari Tansuria, 2011:76)

c. Dalam hal Wajib Pajak juga menerima atau memperoleh penghasilan lainnya selain penghasilan sebagaimana dimaksud pada butir a di atas, maka atas penghasilan lainnya dikenakan $\mathrm{PPh}$ berdasarkan ketentuan perpajakan yang berlaku;

d. Oleh karena atas penghasilan dari pengangkutan orang dan/atau barang, termasuk penghasilan penyewaan kapal telah dikenakan $\mathrm{PPh}$ yang bersifat final, maka dalam pembukuan Wajib Pajak wajib dipisahkan penghasilan dan biaya yang berkenaan dengan pengangkutan orang dan/atau barang termasuk penghasilan penyewaan kapal dari penghasilan dan biaya lainnya. Biaya yang berkenaan dengan pengangkutan orang dan/atau barang termasuk penyewaan kapal tidak boleh dikurangkan dalam melakukan penghitungan penghasilan kena pajak. 


\section{Pemajakan Perusahaan Pelayaran/Penerbangan Luar Negeri}

Tarif PPh Perusahaan Pelayaran Luar

Negeri sesuai dengan Keputusan Menteri Keuangan No. 417/KMK.04/1996 dan Surat Edaran Dirjen Pajak No. SE-32/PJ.4/1996 Tanggal 29 Agustus 1996 tentang Norma Penghitungan Khusus Penghasilan Neto bagi Wajib Pajak yang bergerak di bidang usaha Pelayaran dan/atau Penerbangan Luar Negeri adalah PPh Pasal 15 dengan tariff 2,64\% dari Penghasilan Bruto yang bersifat final. Perhitungan $\mathrm{PPh}$ atas penghasilan pelayaran/penerbangan luar negeri adalah sebagai berikut:

Norma Keputusan Menteri Keuangan No. 417/KMK.04/1996 dan Surat Edaran Dirjen Pajak No. SE32/PJ.4/1996 Tanggal 29 Agustus 1996 tentang Norma Penghitungan Khusus Penghasilan Neto bagi Wajib Pajak yang bergerak di bidang usaha Pelayaran dan/atau Penerbangan Luar Negeri Penghitungan Penghasilan Neto $6,00 \%$

$\begin{array}{lr}\text { PPh Ps. 15 Final }=30 \% \text { x } 6 \%= & \frac{1,80 \%}{4,20 \%} \text { dari peredaran bruto } \\ \text { Laba Setelah PPh Ps. 15 } & \frac{0,84 \%}{3.36 \%} \\ \text { PPh Ps. 26 }=20 \% \text { x 4,20\% } & \\ \text { Laba setelah PPh } & \text { Tarif efektif PPh }=1,80 \%+0,84 \%=2,64 \% \text { bersifat final. }\end{array}$

Maka besarnya $\mathrm{PPh}$ yang wajib dilunasi oleh Wajib Pajak perusahaan pelayaran dan/atau penerbangan luar negeri adalah sebesar $2,64 \%$ dari jumlah peredaran bruto. Peredaran bruto adalah nilai pengganti atau semua imbalan berupa uang dari pengangkutan orang dan/atau barang yang dimuat dari satu pelabuhan ke pelabuhan lain di Indonesia ke pelabuhan di luar negeri. Dengan demikian tidak termasuk penggantian atau imbalan yang diterima atau diperoleh perusahaan pelayaran dan/atau penerbangan luar negeri tersebut dari pengangkutan orang dan/atau barang dari pelabuhan di luar negeri ke pelabuhan di Indonesia.

Untuk perusahaan pelayaran dan/ atau penerbangan luar negeri yang memperoleh penghasilan berdasarkan perjanjian "charter", maka pihak yang membayarkan atau pihak yang "mencharter" wajib memotong PPh terutang pada saat pembayaran atau terutangnya imbalan atau nilai pengganti.
Sementara jika penghasilan diperoleh selain berdasarkan "charter", maka Wajib Pajak perusahaan pelayaran dan/atau penerbangan luar negeri wajib menyetor $\mathrm{PPh}$ yang terutang.(Alsah, 2002:155-156)

\section{Pemajakan Perusahaan Pelayaran Dalam Negeri}

Menurut Alsah (2002: 156), yang dimaksud dengan Wajib Perusahaan Pelayaran Dalam Negeri adalah orang yang bertempat tinggal atau badan yang didirikan dan berkedudukan di Indonesia yang melakukan usaha pelayaran dengan kapal yang didaftarkan baik di Indonesia maupun di luar negeri atau dengan kapal pihak lain.

Tarif PPh Perusahaan Pelayaran Dalam Negeri sesuai dengan Keputusan Menteri Keuangan No. 416/KMK.04/1996 dan Surat Edaran Dirjen Pajak No. SE-29/PJ.4/1996 Tanggal 29 Agustus 1996 tentang Norma Penghitungan Khusus 
TRANSPARANSI

Jurnal Ilmiah Ilmu Administrasi

ISSN 2085-1162

Penghasilan Neto bagi Wajib Pajak yang bergerak di bidang usaha Pelayaran dan/atau Penerbangan Dalam Negeri adalah PPh Pasal 15 dengan tariff $1,2 \%$ dari Peredaran Bruto yang bersifat final.

Peredaran bruto bagi perusahaan pelayaran dalam negeri adalah semua imbalan atau nilai pengganti berupa uang atau nilai uang yang diterima atau diperoleh dari usaha pelayaran tersebut. Norma penghitungan penghasilan neto untuk perusahaan pelayaran dalam negeri adalah sebesar $4 \%$ dari peredaran bruto, dengan demikian besarnya $\mathrm{PPh}$ yang terutang adalah $30 \% \times 4 \%=1,2 \%$ bersifat final. (Alsah,2002: 157).

Pada masa berlakunya

Ordonansi Pajak Perseroan (PPs)

Tahun 1925 dan Pajak Penghasilan 1944, terdapat tarif umum dan tarif khusus. Jadi pada masa itu berlaku schedular taxation yaitu untuk jenis pendapatan tertentu dikenakan pajak dengan tarif tertentu, berbeda dengan jenis penghasilan lain yang dikenakan tarif tertentu yang lain pula. Setelah reformasi perpajakan dengan lahirnya UU PPh 1984, maka konsepnya diubah menjadi Global taxation. (Anwar Pohan, 2014:135)

\section{Global Taxation}

Agar supaya suatu sistem pemungutan pajak atas penghasilan dapat mencapai hasil yang optimal, maka perlu dipilih perlakuan-perlakuan perpajakan yang berpegang teguh kepada pencapaian penerimaan pajak yang memadai untuk dipakai membiayai belanja negara (="The Revenue Adequacy Principle"), dibebankan secara adil kepada semua Wajib Pajak yang mempunyai "ability to pay" untuk dikenakan pajak atas penghasilannya (="The Equality Principle") dan pemungutan pajak tersebut tidak mengurangi effisiensi
Volume VIII, Nomor 02, September 2016

perekonomian (="The Neutrality Principle"). (Mansury, 2000 :34)

Pajak Penghasilan 1984 merupakan global taxation. Global taxation adalah sistem pengenaan pajak atas penghasilan dengan cara menjumlahkan semua jenis tambahan kemampuan ekonomis dimanapun didapat, di Indonesia dan di luar negeri, lalu atas seluruh penghasilan tersebut diterapkan suatu struktur tarif progresif yang berlaku atas semua Wajib Pajak. Kenapa global taxation menjadi sepenuhnya sasaran dari UU $\mathrm{PPh}$. Karena global taxation merupakan sistem pajak atas penghasilan yang paling adil, yakni dengan memakai konsep konsep sebagai sarana untuk mencapai keadilan, baik keadilan horizontal maupun keadilan vertikal dalam pemungutan pajak yang terdapat dalam UU PPh 1984. (Mansury, 1996:82).

Keunggulan Global taxation system adalah sistem ini pada dasarnya memenuhi konsep keadilan dalam perpajakan, yaitu keadilan horizontal dan keadilan vertikal.

\section{Keadilan Pajak (Equality/Equity)}

Pajak adalah iuran rakyat kepada kas Negara berdasarkan Undang-undang (yang dapat dipaksakan) dengan tiada mendapat jasa timbal (kontraprestasi) yang langsung dapat ditunjukkan dan yang digunakan untuk membiayai pengeluaran umum. Pemungutan pajak yang dilakukan oleh pemerintah selain memiliki sifat memaksa juga harus adil. Oleh karena prinsip pemungutan pajak yang baik salah satunya harus bersifat adil.

Sally M. Jones (Principle of Taxation, 2007:124) menegaskan adanya empat standard dalam melakukan pungutan pajak yang baik. Pertama, harus cukup atau bisa meningkatkan pendapatan 
atau penerimaan pemerintah yang diperlukan (should be sufficient to raise the necessary government revenues). Kedua harus mudah bagi pemerintah untuk mengelolanya dan mudah bagi orang untuk membayar (should be convenient for the government to administer and people to pay). Ketiga, efisien dalam ekonomi (should be efficient in economic terms). Keempat, harus adil (should be fair). (Burton, Richard, 2014:188-189).

Isu keadilan merupakan isu yang aktual sepanjang zaman, dari sejak dulu sampai sekarang di belahan dunia manapun isu keadilan ini tetap menjadi salah satu fokus utama yang diangkat dalam berbagai kajian perpajakan yang pada akhirnya bermuara pada bagaimana suatu negara dapat mewujudkan keadilan tersebut bagi seluruh rakyatnya, esensinya menyangkut kemaslahatan umat. Sebagai instrumen pajak, keadilan (equality/equity) dan pemerataan (equality) adalah sepasang perangkat yang senantiasa setia mengawal masyarakat agar tidak dirugikan oleh pelaksana hukum atau aturan yang dibuat secara yang semena-mena oleh penguasa. Secara universal, tujuan hukum pajak sebagaimana tujuan hukum pada umumnya, bertujuan menciptakan keadilan dalam pungutan pajak, dan siapapun yang berada dalam lingkup penegakan hukum (law enforcement) tersebut asas ini harus dipegang teguh baik dalam prinsip perundang-undangan maupun dalam prakteknya sehari-hari. Keadilan tersebut memang tidak eksak, melainkan bersifat subjektif dan relatif, sehingga ketika terjadi sesuatu permasalahan di bidang perpajakan yang menonjolkan keadilan, seringkali hal ini menjadi bahan perdebatan dengan argumentasi yang beragam. Dalam perpajakan, apakah keadilan selalu mesti di kedepankan?, secara teoritis dan filosofisnya memang harus demikian, tetapi dalam prakteknya tidak ada suatu garansi bahwa hasil akhir implementatifnya harus demikian, bahkan bisa saja dikebelakangkan karena alasan mendahulukan kepentingan tertentu yang lebih esensil yang notabene menimbulkan ketidakadilan bagi masyarakat umum. (Anwar Pohan, 2014:119)

Sejarah membuktikan bahwa ketidakadilan dalam pemungutan pajak dapat menimbulkan revolusi, seperti halnya terjadi di Perancis dan Inggeris. Ketika terjadi revolusi Perancis (17891799) yang pada saat itu terdapat perbedaan yang sangat mencolok antara rakyat miskin yang dibebani berbagai macam pajak dengan kaum bangsawan yang dibebaskan dari segala macam pajak, rakyat miskin akhirnya memperoleh kemenangan dalam revolusi tersebut, dan setelah itu diciptakanlah suatu asas perpajakan yakni pajak harus bersifat umum dan merata. Karena hanya dengan kedua asas/prinsip itulah pajak dapat menyentuh rasa keadilan masyarakat (Mansury, 1994:25). Terlebih lagi negara Indonesia yang menganut ideologi Pancasila, dengan salah satu silanya "Keadilan sosial bagi seluruh rakyat Indonesia", maka landasan pemikiran dalam setiap perumusan perundang-undangan perpajakan yang berbasiskan semboyan tersebut seharusnya lebih implementatif dalam regulasi dan pelaksanaannya dan merupakan sendi pokok yang seharusnya diperhatikan sebaikbaiknya dalam dalam pemungutan pajak.

Menurut Adam Smith, prinsip yang paling utama dalam rangka pemungutan pajak adalah keadilan dalam perpajakan yang dinyatakan dengan suatu pernyataan bahwa setiap warga negara hendaknya berpartisipasi dalam pembiayaan pemerintah, yaitu dengan cara membandingkan 
TRANSPARANSI

Jurnal Ilmiah Ilmu Administrasi

ISSN 2085-1162

penghasilan yang diperolehnya dengan perlindungan yang dinikmatinya dari negara. Asas keadilan yang disebut oleh Adam Smith sebagai "The Equity Principle"(salah satu dari teori Four Maxims/Cannon yang dicetuskan oleh Adam Smith), yaitu bahwa pemungutan pajak harus dibebankan secara adil : Pertama, pajak itu harus dibebankan kepada masyarakat berdasarkan manfaat yang dinikmati oleh anggota masyarakat yang bersangkutan. Kedua, apabila masih diperlukan penerimaan lebih besar, sedangkan manfaat dari belanja negara tersebut yang dinikmati masing-masing wajib pajak tidak bisa ditentukan, seperti pertahanan nasional dan kantibmas, serta belanja negara untuk membeli sembako guna dibagikan kepada rakyat miskin, maka pajak dipungut dari masyarakat berdasarkan kemampuan membayar masing-masing wajib pajak. Teori tersebut selanjutnya dikembangkan oleh Adolf Wagner, seorang ahli ekonomi berkebangsaan Jerman (yang hidup dari tahun 1835 sampai dengan tahun 1917) yang mengemukakan bahwa pemungutan pajak yang adil adalah pemungutan pajak yang diberlakukan secara umum kepada semua wajib pajak dan dibebankan kepada setiap wajib pajak yang mempunyai ability to pay secara merata, bahwa satu struktur tarif pajak berlaku kepada setiap wajib pajak yang mempunyai kemampuan membayar. Semakin besar ability to pay seorang wajib pajak, semakin besar prosentasi pajak yang harus dibayar. Keadilan vertikal ini bertujuan untuk melakukan redistribusi penghasilan menuju kepada distribusi penghasilan yang lebih baik. Menurut Adolf Wagner, pajak atas penghasilan yang dipungut dengan menerapkan suatu tarif pajak yang progresif merupakan pelaksanaan fungsi mengatur dari perpajakan. (Mansury, 2000:3).
Salah satu sasaran dari pembaharuan sistem perpajakan tahun 1984 adalah "Keadilan dalam pembebanan pajak", baik Keadilan Horizontal maupun Keadilan Vertikal. Memperbaiki prinsip keadilan dan pemerataan yang terdapat dalam sistem perpajakan yang baru diharapkan akan memperbaiki dan mengembalikan kepercayaan masyarakat pembayar pajak akan adanya keadilan dalam perpajakan. Berdasarkan hal itu tidak ada lagi perbedaan perlakuan diantara wajib pajak, artinya setiap orang mendapat perlakuan yang adil di dalam masalah pajak. Oleh karena itulah salah satu sasaran dari pembaharuan sistem perpajakan nasional adalah pemerataan dalam pengenaan pajak, yang mencerminkan asas keadilan secara horizontal. Setiap orang yang memperoleh tambahan kemampuan ekonomi yang sama, tanpa membedakan dari mana sumber tambahan tersebut, dikenakan pajak penghasilan yang sama besar. Azas keadilan secara vertikal pada dasarnya berkenaan dengan penentuan besarnya pajak terhutang yang harus dibayar oleh wajib pajak. Hal itu serta kaitannya dengan penentuan besarnya tarif pajak. Beban pajak seharusnya dibagi berdasarkan kemampuan untuk membayar kontribusi guna membiayai kegiatan pemerintah. Ukuran bagi kemampuan untuk membayar (ability to pay) beban pajak dapat berupa penghasilan netto, bisa juga berupa kekayaan, maupun berupa pengeluaran belanja untuk konsumsi, atau kombinasi dari kedua ketiga ukuran tersebut. (Anwar Pohan, 2014:121)

Apabila penghasilan netto yang dipakai sebagai ukuran mencapai keadilan diantara wajib pajak, tidak sama maka disyaratkan agar tarif pajaknya juga berbeda. Makin besar penghasilan netto seorang wajib pajak, semakin besar pula tarif pajak yang 
dikenakan terhadapnya. Keadilan horizontal mensyaratkan, setiap tambahan kemampuan untuk menguasai barang dan jasa, tanpa dibedakan dari manapun sumbernya harus dikenakan pajak yang sama. Sedangkan keadilan vertikal mensyaratkan adanya struktur tarif yang progresif seperti yang terdapat pada pasal 17 UU PPh tahun 1984, yaitu semakin besar penghasilan netto seorang wajib pajak, maka semakin besar pula tarif pajaknya. Salah satu sasaran dari pembaharuan sistem perpajakan tahun 1984 adalah "keadilan dalam pembebanan pajak," baik keadilan horizontal maupun keadilan vertikal, dan sistem pajak penghasilan yang paling adil adalah global taxation system karena sistem ini menggunakan konsep-konsep sebagai sarana untuk mencapai baik keadilan horizontal maupun keadilan vertikal.

Dalam perpajakan dikenal 2 (dua) macam keadilan, yaitu Keadilan Horizontal dan Keadilan Vertikal (Mansury,1996:11-12) :

1. Keadilan Horizontal (Horizontal Equity) mengandung pengertian bahwa penyelenggaraan pajak harus secara umum dan merata, yang berarti semua orang mempunyai kemampuan ekonomis atau yang mendapat tambahan kemampuan ekonomis yang sama harus dikenakan pajak yang sama.

2. Keadilan Vertikal (Vertical Equity) pada hakekatnya berkenaan dengan kewajiban membayar pajak yang kemampuan membayarnya tidak sama, yaitu semakin besar kemampuannya untuk membayar pajak harus semakin besar tarif pajak yang dikenakan.

Keadilan horizontal adalah keadilan yang dicapai melalui pengenaan pajaknya sama atas semua tambahan kemampuan ekonomis yang sama tamnpa membedakan sumber penghasilannya dan tanpa membedakan jenis-jenis penghasilan. Wajib Pajak yang mendapatkan penghasilan yang sama dengan jumlah tanggungan yang sama tanpa membedakan jenis penghasilan atau sumber penghasilan akan dikenakan pajak yang sama pula, diterapkan hanya satu macam struktur pajak, atau biasa disebut equal treatment for the equals.

Keadilan vertikal adalah keadilan yang dicapai melalui pengenaan pajak yang berbeda apabila jumlah penghasilan seorang wajib pajak berbeda. Semakin besar jumlah penghasilan seorang wajib pajak akan semakin besar tarif pajak yang harus dikenakan atas wajib pajak tersebut. (Mansury, 1996:82)

Keadilan vertikal mensyaratkan adanya

- struktur tarif yang progresif, yaitu semakin besar penghasilan neto seorang wajib pajak, maka tarif pajaknya harus semakin besar;

- yang membedakan besarnya tarif adalah jumlah seluruh penghasilan atau jumlah seluruh tambahan kemampuan ekonomis, bukan karena perbedaan sumber penghasilan atau perbedaan jenis penghasilan, atau biasa disebut dengan unequal treatment for the unequals.

(Mansury, 1996:68-69).

Asas keadilan secara vertikal pada dasarnya berkenaan dengan penentuan besarnya pajak terutang yang harus dibayar oleh wajib pajak. Hal ini erat kaitannya dengan penentuan besarnya tarif pajak. Beban pajak seharusnya dibagi berdasarkan kemampuan untuk membayar kontribusi guna membiayai kegiatan pemerintah. Ukuran bagi kemampuan membayar (ability to pay) beban pajak dapat berupa penghasilan netto, bisa juga berupa kekayaan maupun berupa pengeluaran belanja untuk konsumsi atau kombinasi dari kedua atau ketiga 
TRANSPARANSI

Jurnal Ilmiah Ilmu Administrasi

ISSN 2085-1162

ukuran tersebut. (Anwar Pohan, 2014:136)

Dengan perkataan lain, keadilan horizontal menyangkut pengertian penghasilan, sedangkan keadilan vertikal menyangkut stuktur tarif. Lebih jelas dikemukakan oleh pakar public finance, yakni Joseph Pechman dan Benyamin Okner yang mengembangkan pengertian keadilan horizontal, sedangkan Harvey S. Rosen mengembangkan pengertian keadilan vertikal.

Joseph Pechman dan Benyamin Okner menuangkan hasil penelitian mereka dalam bukunya yang berjudul "Who Bears the Tax Burden" (Washington D.C:The Brookings Institution, 1974) dan kemudian hasil penelitian mereka tersebut dijelaskan oleh A.B. Atkinson dengan tulisannya yang berjudul "Horizontal Equity and the Distribution of the Tax Burden" dalam buku The Economics of Taxation yang diedit oleh Henry J Aaron dan Michael J.Boskin (Washington D.C.:The Brookings Institution, 1980). The concept of horizontal equity adalah mengenai beban pajak atas orang orang yang jumlah besar penghasilannya sama dan besarnya tanggungannya adalah sama. Jadi suatu pemungutan pajak adalah adil secara horizontal, apabila beban pajaknya adalah sama atas semua wajib pajak yang mendapatkan penghasilan yang sama dengan jumlah tanggungan yang sama, tanpa membedakan jenis penghasilan atau sumber penghasilan.

Sedangkan mengenai keadilan vertikal, menurut Harvey S. Rosen dalam bukunya Public Finance (1988:321) menuliskan: "It is widely agreed that tax system should have vertical equity : It should distribute burden fairly accross people with different abilities to pay".

Dari kedua pengertian keadilan tersebut tersebut menurut Mansury bila dirumuskan dalam satu kalimat, bahwa pemungutan pajak adalah adil, apabila orang-orang yang berada dalam keadaan ekonomis yang sama dikenakan pajak yang sama, sedangkan orang-orang yang keadaan ekonomisnya tidak sama harus diperlakukan tidak sama setara dengan ketidaksamaannya itu. (Mansury, 1996:9-10).

Mansury(1996:11-12)

mengemukakan syarat keadilan horizontal \& vertikal sebagai berikut :

1. Syarat keadilan Horizontal (Horizontal Equity)

Keadilan Horizontal dapat dicapai jika dipenuhi lima syarat sebagai berikut :

a. Definisi Penghasilan : Semua tambahan kemampuan ekonomis, yaitu semua tambahan kemampuan untuk dapat menguasai barang dan jasa, dimasukkan dalam pengertian objek pajak atau definisi penghasilan

b. Globality : Semua tambahan kemampuan itu merupakan ukuran dari keseluruhan kemampuan membayar atau "the global ability to pay", oleh karena itu harus dijumlahkan menjadi satu sebagai obyek pajak.

c. Nett Income : Yang menjadi ability to pay adalah jumlah netto setelah dikurangi semua biaya mendapatkan, menagih dan memelihara penghasilan (biaya 3M)

d. Personal Exemption : Untuk wajib pajak orang pribadi, suatu pengurangan untuk memelihara diri wajib pajak harus diperkenankan. Dalam Undangundang $\mathrm{PPh}$ kita disebut Penghasilan Tidak Kena Pajak (PTKP). 
e. Equal treatment for the equals : Jumlah seluruh penghasilan yang memenuhi definisi penghasilan, apabila jumlahnya sama dikenakan pajak dengan tarif pajak yang sama, tanpa membedakan jenis-jenis penghasilan atau sumber penghasilan.

\section{Syarat keadilan Vertical (Vertical Equity)}

Keadilan Vertikal dapat dicapai jika dipenuhi dua syarat sebagai berikut :

a. Unequal treatment for the unequals: Yang membedakan besarnya tariff pajak adalah jumlah seluruh penghasilan atau jumlah seluruh tambahan kemampuan ekonomis, bukan karena perbedaan sumber penghasilan atau perbedaan jenis penghasilan.

b. Progression : Bila jumlah penghasilan seorang wajib pajak lebih besar, dia harus membayar pajak lebih besar dengan menerapkan tarif pajak yang prosentasenya lebih besar.

Dasar teori tentang keadilan dalam pemungutan pajak ini diperkuat oleh Musgrave, Richard A. dan Peggy Musgrave (1989:61-94), mengemukakan dua pendekatan yang merupakan dasar bagi fiskus untuk memungut pajak, yakni Benefit principle dan Ability to pay principle, yang telah dibahas terdahulu, sebagai berikut:

1. Benefit Principle (disebut juga Revenue \& Expenditure Approach)

2. Ability to pay principle: (a).

Horizontal equity dan (b). Vertical equity

Benefit Principle adalah prinsip pengenaan pajak berdasarkan atas manfaat yang diterima oleh seseorang wajib pajak dari pembayaran pajaknya itu kepada pemerintah.
Ability to pay principle adalah prinsip kemampuan untuk membayar atau berdasarkan atas daya pikul seorang wajib pajak. Seorang Wajib Pajak akan dikenai beban pajak sesuai dengan kemampuannya membayar. Wajib Pajak yang memiliki kemampuan membayar yang sama dikenai pajak yang sama bebannya (horizontal equity), dan Wajib Pajak yang kemampuannya berbeda dikenai pajak yang berbeda pula bebannya (vertical equity). (Suparmoko, 2013: 132-133).

Beberapa penekanan khusus dari kedua pendekatan tersebut diatas dapat kita catatkan berikut ini (Anwar Pohan, 2014:123) :

a. Dalam suatu sistem perpajakan yang adil, bila pada pendekatan pertama (benefit principle), setiap wajib pajak harus membayar sejalan dengan manfaat yang dinikmatinya dari kegiatan pemerintah, sehingga jumlah pajak yang harus dibayar itu harus berbeda sesuai dengan jumlah pengeluaran untuk melakukan kegiatan pemerintah, maka pada pendekatan kedua (ability to pay principle) pajak dibebankan kepada para wajib pajak berdasarkan kemampuan untuk membayar masing-masing.

b. Bila pada pendekatan kedua (ability to pay principle), dapat diterapkan secara umum untuk memungut pajak yang diperlukan untuk membiayai semua kegiatan pemerintah, maka pada pendekatan pertama (benefit principle) pemungutan pajak hanya dapat diterapkan untuk membiayai kegiatan pemerintah tertentu di bidang public utilities.

Pendekatan benefit tidak dapat diterapkan :

1) untuk jasa pertahanan keamanan serta kegiatan pemerintah lainnya yang manfaatnya sulit ditentukan 
TRANSPARANSI

Jurnal Ilmiah Ilmu Administrasi

ISSN 2085-1162

2) untuk untuk wajib pajak orang per orang, dan

3) untuk membiayai kegiatan pemerintah melakukan redistributive function-nya, yaitu pungutan pajak kepada wajib pajak yang kaya yang fungsinya agar dapat didistribusikan/dialokasikan kembali (secara tidak langsung) kepada masyarakat untuk meningkatkan kesejahteraan orang miskin.

Dalam penentuan "tax policy options", yang baik selalu memperhatikan kemudahan dalam pelaksanaan pemungutan pajak. Apabila ada dua alternatif yang berbeda untuk mencapai sasaran yang sama, maka dari kedua alternatif tersebut harus dipilih yang lebih mudah untuk dilaksanakan pemungutannya. Hanya saja yang perlu kita ingat, jangan sampai "for the ease of administration" itu dikejar dengan mengorbankan penerapan azas-azas yang harus dipegang teguh, misalnya untuk mengejar kemudahan pemungutan pajak, lalu pengenaan pajak tersebut tidak adil. (Mansury, 1996:68).

Penerangan Azas Keadilan dalam PPh justru terganggu karena ada penghasilan yang dikecualikan dan ada penghasilan-penghasilan tertentu yang dikenakan PPh dengan tariff yang lebih rendah dari penghasilan-penghasilan lain (Mansury, 1996:11).

Richard Goods dalam bukunya "The Individual Income Tax" (Washington D.C.:The Brookings Institution, revised edition, 1978) menyebut pajak atas penghasilan itu sebagai "the fairest of the major taxes". Maka kenapa kita memilih $\mathrm{PPh}$ untuk dipungut setelah kita memutuskan untuk memungut pajak, adalah karena $\mathrm{PPh}$ dapat dipakai
Volume VIII, Nomor 02, September 2016

untuk memungut pajak secara adil. Namun perlu diperhatikan, bahwa keadilan itu dapat tercapai, apabila dipilih perlakuan-perlakuan pajak yang menjamin tercapainya keadilan itu. (Mansury, 1996 :10\&15)

\section{The Revenue Adequacy Principle}

Pada waktu ini Azaz Kecukupan Penerimaan atau "The Revenue Adequacy Principle" yang dikemukakan oleh Jesse Burkhead dalam tulisannya "Tax" dalam Encyclopedia Americana (Danbury,Connecticut: Americana Corporation, International Headquartetrs, Volume 26, 1978) dianggap di banyak Negara, terutama di negara-negara berkembang, termasuk Indonesia, sebagai azas yang sangat penting. Istilah "The Revenue Adequacy Principle" dipergunakan dalam arti Pajak dipungut untuk mengumpulkan penerimaan Negara yang akan dipakai untuk membiayai barang-barang publik dan jasa yang diperlukan oleh masyarakat secara keseluruhan.(Mansury, 2000:1)

\section{Freight}

Dalam pengoperasian kapal, kita mengenal istilah uang tambang atau ongkos pengangkutan (freight).

Menurut Suyono (2005:154) :

Uang tambang adalah uang yang diminta oleh perusahaan pelayaran untuk kompensasi biaya atas jasa mengangkut barang. Uang tambang dapat dipungut berdasarkan jenis barang (commodity based), dimana uang tambang akan disesuaikan dengan jenis barangnya. Dengan banyaknya jenis barang tentunya uang tambang berbeda-beda pula. Untuk memudahkan pemungutan uang tambang, maka diberikan alternatif lain, yaitu mengenakan 
uang tambang berdasarkan satuan/per unit.

Freight adalah suatu imbalan/balas jasa yang dibayarkan kepada pengangkut (shipping Freight charges). Freight charges adalah biaya transportasi yang sebenarnya dibayar atau menggunakan moda angkutan berupa pesawat, kapal, dan/atau kereta api. Termasuk dalam pengertian freight charges adalah biaya-biaya yang dikeluarkan yang terkait dengan biaya transportasi dengan menggunakan moda angkutan pesawat, kapal, dan/atau kereta api tersebut, antara lain fuel surcharge. (SE. No. 33/PJ/2013 yang diunduh dari www.pajak.go.id. tgl. 21/5/14 jam 13.30).

Mengutip definisi menurut Cive M. Schmittoff dalam bukunya The Export, London, Stevens\&Son, 1980, halaman 336 yang dikutip dari F.D.C. Sudjatmiko, Pokok-Pokok Pelayaran Niaga, Edisi Kedua, Akademika Pressindo, CV, Jakarta, 1985 hal. 103-104 (Pohan, 2001:30) :

"Freight is a reward payable of the carrier for the safe carriage and delivery of the goods; it is payable only on the safe carriage and delivery; if the goods are the lost on the voyage, nothing is payable" (maksudnya : freight/uang tambang adalah suatu imbalan yang dibayarkan kepada pengangkut (carrier) atas pengangkutan dan penyerahan barang-barang yang dilaksanakan dengan selamat; uang tambang itu hanya dibayar pada pengangkutan dan penyerahan barang-barang yang dilaksanakan dengan selamat; bilamana barangbarang hilang dalam perjalanan pengangkutan, tidak ada kewajiban untuk membayar apapun kepada pengangkut)

Menurut Stevens (1982:95) :
"Freight is the consideration payable to the carrier for the safe carriage and delivery of goods in a merchantable condition"

(maksudnya : freight adalah upah/uang yang dibayarkan kepada pengangkut atas pengangkutan dan penyerahan barang yang telah dilaksanakan dengan selamat dalam kondisi diperdagangkan)

\section{Asas Pemungutan Pajak}

Menurut Adam Smith, pemungutan pajak hendaknya didasarkan atas empat kaidah/azas perpajakan, yakni asas kesamaan dan keadilan (equality and equity), asas kepastian hukum (certainty), asas tepat waktu (convenience), dan asas ekonomi atau efisiensi (economy or efficiency (Hamonangan Simanjuntak,2012:24).

Keadilan merupakan prinsip dasar pemajakan atas penyerahan barang atau jasa kena pajak yang harus dijadikan suatu kriteria dalam perumusan, pemilihan dan penilaian kebijakan pajak dan ketentuan perpajakan. Untuk meningkatkan keadilan, dalam perubahan Undang-undang PPN 2000 telah diambil kebijakan perluasan objek PPN (Pasal 4A dan Pasal 16D), penghapusan fasilitas perpajakan serta kenaikan tariff pajak penjualan barang mewah.

Dengan demikian azas kepastian hukum (certainty) sangat penting untuk menghindari terjadinya dispute persepsi antar fiskus dengan wajib pajak dalam menafsirkan nilai tambah freight yang pada akhirnya berpengaruh pada perbedaan dalam perlakuan perpajakannya.

Menurut Adam Smith, kepastian adalah lebih penting dari keadilan. Jadi suatu sistem yang telah dirancang menurut azas keadilan, tanpa kepastian bisa tidak adil atau tidak selalu adil. Mansury, Guru Besar Ilmu Perpajakan UI, berpendapat, bahwa seharusnya kepastian itu harus menjamin 
TRANSPARANSI

Jurnal Ilmiah Ilmu Administrasi

ISSN 2085-1162

tercapainya keadilan dalam pemungutan pajak, yakni kepastian tentang subyek pajak, obyek pajak, tariff pajak dan prosedur pajak, harus menjamin keadilan yang ingin dicapai

Metode penelitian merupakan cara ilmiah yang digunakan untuk mendapatkan data dengan tujuan tertentu. Dengan cara ilmiah itu, diharapkan data yang akan didapatkan adalah data yang objective, valid, dan reliable. Objective berarti semua orang akan memberikan penafsiran yang sama, valid berarti adanya ketepatan antara data yang terkumpul oleh peneliti dengan data yang terjadi pada obyek yang sesungguhnya, dan reliable berarti adanya ketetapan/keajegan/konsisten data yang didapat dari waktu ke waktu.

Metode penelitian yang digunakan dalam penelitian ini adalah metode deskriptif. Menurut Nazir (1988:63), metode deskriptif adalah suatu metode dalam meneliti status sekelompok manusia, suatu objek, suatu set kondisi, suatu sistem pemikiran ataupun suatu kelas peristiwa pada masa sekarang. Tujuan dari penelitian deskriptif ini adalah untuk membuat deskripsi, gambaran atau lukisan secara sistematis, faktual dan akurat menangani fakta-fakta, sifat-sifat serta hubungan antar fenomena yang diselidiki. Sedangkan Metode deskriptif menurut Sugiyono (2012:6) adalah "Metode penelitian yang dilakukan terhadap variabel mandiri, yaitu tanpa membuat perbandingan, atau menghubungkan dengan variabel yang lain".

Sedangkan pendekatan penelitian yang digunakan adalah pendekatan kualitatif. Pada metode penelitian kualitatif ini, metode penelitian yang digunakan untuk meneliti pada kondisi obyek yang alamiah (sebagai lawannya adalah eksperimen), dimana peneliti adalah sebagai instrumen kunci, teknik
Volume VIII, Nomor 02, September 2016

melalui tax treatment tertentu (Mansury, 1996:5-6).

\section{METODE PENELITIAN Pendekatan Penelitian}

pengumpulan data dilakukan secara trianggulasi (gabungan), analisa data bersifat induktif, dan hasil penelitian kualitatif lebih menekankan makna dari pada generalisasi. Teknik trianggulasi adalah pengumpulan data yang menggunakan berbagai sumber dan berbagai teknik pengumpulan data secara simultan sehingga dapat diperoleh data yang pasti. Generalisasi dalam penelitian kualitatif dinamakan transferability, artinya hasil penelitian tersebut memiliki karakteristik yang tidak jauh berbeda. (Sugiyono, 2010:1-3).

Data kualitatif berupa hasil wawancara mendalam, observasi, studi kepustakaan dan dokumentasi, namun juga dimungkinkan menggunakan data kuantitatif sebagai pelengkap informasi pada setiap pertanyaan analisis penelitian.

Dalam penelitian ini, penulis menggunakan pendekatan kualitatif, menurut Sugiyono (2010:1) bahwa :

Metode penelitian kualitatif adalah metode penelitian yang digunakan untuk menelit pada kondisi obyek yang alamiah atau natural setting, (sebagai lawannya adalah eksperimen) dimana peneliti adalah sebagai instrument kunci, teknik pengumpulan data dilakukan secara trianggulasi (gabungan), analisis data bersifat induktif, dan hasil penelitian kualitatif lebih menekankan makna dari pada generalisasi.

Teknik trianggulasi adalah pengumpulan data yang menggunakan berbagai sumber dan berbagai teknik pengumpulan data secara simultan, sehingga dapat diperoleh data yang pasti. 


\section{MODEL ALUR PIKIR PENELITIAN}

\section{PERHITUNGAN PPh BERDASARKAN KONSEP GLOBAL TAXATION PADA PERUSAHAAN PELAYARAN NASIONAL YANG DIUSULKAN (Berdasarkan laporan keuangan dari enam perusahaan pelayaran nasional yang diteliti)}

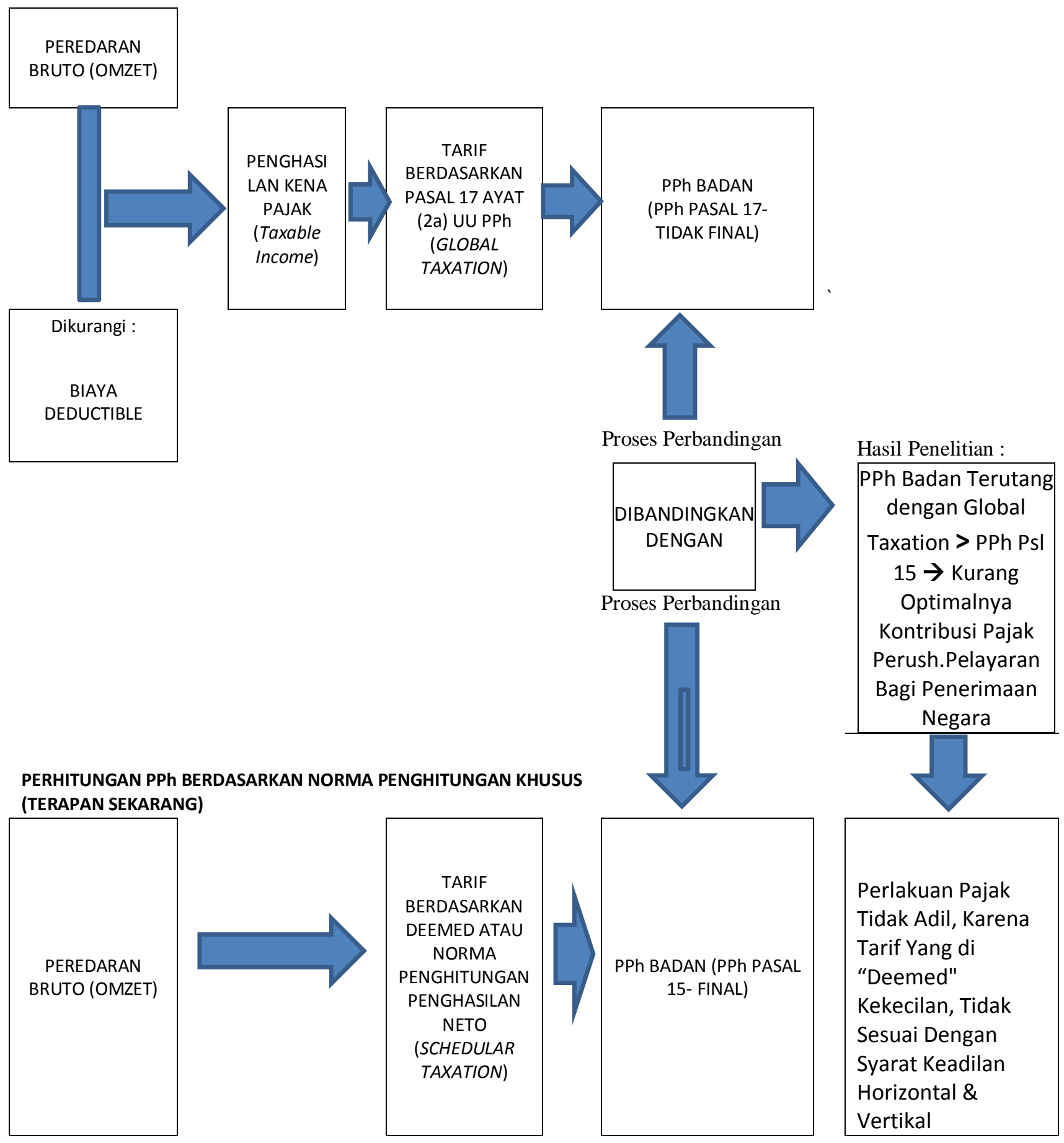

\section{PEMBAHASAN}

Semenjak DPR mengesahkan UndangUndang No. 7 Tahun 1983 tentang Pajak Penghasilan, sebagaimana telah diubah terakhir dengan Undang-Undang No. 36 Tahun 2008 (jadi ada empat kali perubahan, yakni dengan UU No. 7/1991, kemudian No.10/1994, selanjutnya No.17/2000 dan terakhir No. 36/2008), 
TRANSPARANSI

Jurnal Ilmiah Ilmu Administrasi

ISSN 2085-1162

tetapi basis pemajakan perusahaan pelayaran dalam negeri dan luar negeri yang menerapkan Norma Penghitungan Khusus Penghasilan Neto (deemed profit) bagi Wajib Pajak perusahaan pelayaran dalam dan luar negeri dengan penerapan Pajak Penghasilan Pasal 15 (bersifat Final) tidak mengalami perubahan baik dalam Tarif dan Dasar Pengenaan Pajaknya, padahal tarif Pajak Penghasilan Badan (Pasal 17 ayat 2a) telah mengalami perubahan mulai dari UU No. 7 tahun 1983 dengan tarif progressif 10\%-35\% terakhir berubah dengan tarif tunggal sebesar $25 \%$ dalam UU No. 36 Tahun 2008. Demikian pula dengan Dasar Pengenaan Pajak yang digunakan kelihatannya sudah tidak wajar dengan Penghasilan Neto pelayaran luar negeri sebesar 6\%.

Dasar Pengenaan Pajak yang mencerminkan rate of return perusahaan yang digunakan sebagai basis pemajakan pajak penghasilan perusahaan pelayaran nampaknya terlalu rendah, dibandingkan dengan tingkat keuntungan (net profit after tax) yang diperoleh perusahaan pelayaran dalam dan luar negeri. Kondisi ini tentu saja berdampak pada rendahnya penerimaan pajak dari sektor usaha pelayaran, dan selain itu aspek pemenuhan kaidah keadilan pajak juga terganggu karena bagi perusahaan pelayaran yang mengalami kerugian tetap saja bayar pajak final (PPh Pasal 15).

Data berupa audited Financial Statements yang dikumpulkan dari perusahaan-perusahaan terbuka yang telah go public dan terdaftar di Bursa Efek Indonesia sub sektor transportasi, yang diunduh dari website Bursa Efek Indonesia tgl. 25 Januari 2015 sebanyak 8(delapan) perusahaan pelayaran, dalam tahun 2012 dan 2013, yakni :
a. PT. Pelayaran Nasional Bina Buana Raya, Tbk.
b. PT. Pelayaran Nelly Dwi Putri, Tbk.
c. PT. Logindo Samudra Makmur, Tbk.

\author{
d. PT. Mitrabahtera Segara \\ Sejati, Tbk. \\ e. PT. Wintermar Offshore \\ Marine, Tbk. \\ f. PT. Transpower Marine, \\ Tbk. \\ g. PT. Tempuran Mas, Tbk. \\ h. PT. Trada Maritime, Tbk.
}

Berdasarkan data audited financial statements tahun 2012 dan 2013 dari masing-masing perusahaan pelayaran tersebut diatas, dan hasil rekonsiliasi fiskal perhitungan $\mathrm{PPh}$ Badan yang disajikan dalam audited report-nya untuk menghitung $\mathrm{PPh}$ Badan terutang yang berbasiskan pada norma penghitungan penhasilan netto dengan tariff PPh Pasal 15 sebagaimana terlampir dalam daftar lampiran hasil penelitian ini, selanjutnya penulis melakukan analisa komparatif dengan menyajikan table 4-1 sebagaimana terlampir dalam lampiran-1 ini.

\section{Reviu Pengenaan PPh Pasal 15 (Final) Pada Perusahaan Pelayaran Nasional Di Indonesia Ditinjau Dari Azas Kecukupan Penerimaan Negara}

Dalam melakukan Rekonsiliasi Fiskal seperti Nampak dalam Tabel 4-1, Laba sebelum PPh harus dikurangi Laba/(Rugi) Entitas Anak untuk mendapatkan Laba sebelum Taksiran PPh. Sedangkan koreksi fiskal dilakukan berdasarkan data yang ada dalam audit report. Namun untuk maksud perhitungan PPh Badan yang terutang dikeluarkan dari Laba sebelum Taksiran PPh : 1. Penghasilan bunga yg sudah dikenakan PPh Final 2. Beban yang tidak dapat dikurangkan lainnya.

Dengan asumsi kurs tengah BI tanggal 31 Desember 2013 sebesar Rp. 12.189/USD1 dan tanggal 31 Des 2012 sebesar Rp.9.670/USD1, maka diperoleh besarnya laba sebelum $\mathrm{PPh}$ menurut Fiskal seharusnya sebesar Beban PPh badan menurut SPT PPh Badan (per audit report) yang menggunakan tarif asal 17 
ayat (2) sebesar Rp1.450.803.556.578 untuk tahun 2013 dan Rp. 1.015.939.021.265 untuk tahun 2012.

Selanjutnya bila diikhtisarkan kinerja keuangan dari keenam perusahaan pelayaran tersebut, maka akan terlihat selisih perhitungan PPh Badan terutang yang telah dibayar antara Beban PPh Badan Versi Audit Report (PPh Psl. 15 final) dibandingkan dengan Beban PPh Badan dgn Tarif $25 \%$ yang sesuai Pasal 17 ayat 2a UU PPh, seperti terlihat dalam rekapitulasi di tabel 4-2 berikut ini :

Tabel 4-2

Analisis Perbandingan Beban PPh Menurut SPT PPh Badan (per audit report) Dengan PPh Badan Menurut Global Taxation

\begin{tabular}{|c|c|c|}
\hline & \multicolumn{2}{|c|}{$\begin{array}{c}\text { TOTAL } \\
\text { (6 Perusahaan Pelayaran) } \\
\text { Dalam Rp. }\end{array}$} \\
\hline & 2013 & 2012 \\
\hline $\begin{array}{l}\text { Beban PPh - dalam Rp menurut SPT PPh Badan } \\
\text { (per audit report) } \\
\text { (A) }\end{array}$ & $\begin{array}{c}90.140 .909 .591 \\
24.85 \%\end{array}$ & $\begin{array}{c}57.790 .850 .008 \\
22.75 \%\end{array}$ \\
\hline $\begin{array}{l}\text { LABA SEBELUM PPh -dalam USD menurut } \\
\text { Fiskal seharusnya } \\
\text { LABA SEBELUM PPh - dalam Rp menurut } \\
\text { Fiskal seharusnya }\end{array}$ & 1.450 .803 .556 .578 & 1.015.939.021.265 \\
\hline $\begin{array}{l}\text { PPh Badan Menurut Global Taxation : } 25 \% \\
\text { Sebagai Pembanding } \\
\begin{array}{ll}\text { Selisih PPh Badan } & \text { (B) - (A) }\end{array}\end{array}$ & $\begin{array}{r}362.700 .889 .145 \\
100 \% \\
272.559 .979 .554\end{array}$ & $\begin{array}{r}253.984 .755 .316 \\
100 \% \\
196.193 .905 .308\end{array}$ \\
\hline$(A):(B)$ & $75.15 \%$ & $77.25 \%$ \\
\hline
\end{tabular}

Sumber : Laporan Keuangan Yang Diaudit (Audited Financial Statements) Tahun 2012 dan 2013 dari keenam entitas yang terdaftar di Bursa Efek Indonesia (yang diolah penulis)

Tabel 4-2 tersebut menunjukkan bahwa untuk keenam perusahaan pelayaran yang sudah Tbk dalam kurun waktu tersebut ternyata :

1. Jumlah PPh Badan Terutang bila dikenakan menurut konsep Global Taxation adalah lebih besar dari pengenaan berdasarkan PPh Pasal 15.

2. Negara mengalami kekurangan dalam penerimaan pajak dengan kisaran sebesar $75-77 \%$ dari jumlah yang seharusnya diterima bila pengenaan pajak badan pada perusahaan pelayaran nasional tbk. mengacu pada konsep global taxation daripada menggunakan schedular taxation (norma penghitungan khusus yakni PPh Pasal 15 yang bersifat final).

Selanjutnya kita dapat menganalisa seberapa besar potensi kerugian atau kurangnya penerimaan Negara dari PPh Badan yang terutang secara komparatif dalam Tahun 2013 dan 2012 antara PPh Badan Menurut Audit Report dengan penerapan tariff 25\% (Pasal 17 ayat 2a UU PPh) dengan Beban PPh Badan Versi Audit Report (PPh Psl. 15 final), seperti nampak dalam Tabel 4-3 berikut ini.

Tabel 4-3

Perhitungan PPh Badan Terutang secara komparatif Tahun 2013 Vs 2012 antara PPh Badan Menurut Audit Report dengan Tarif 25\% Sesuai Pasal 17 ayat 2a UU PPh 


\section{Tahun 2013}

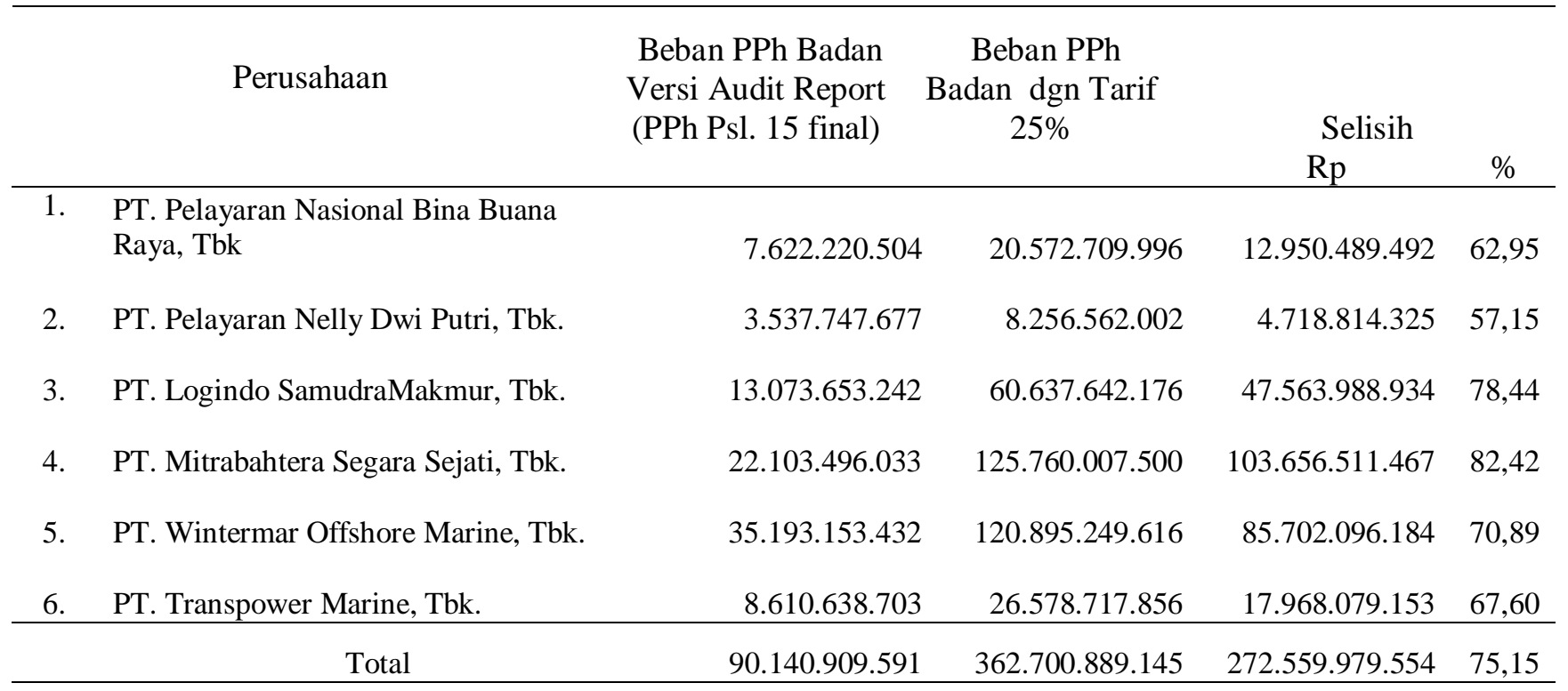

Tahun 2012

\begin{tabular}{|c|c|c|c|c|c|}
\hline No. & \multirow[t]{2}{*}{ Perusahaan } & \multirow[t]{2}{*}{$\begin{array}{c}\text { Beban PPh } \\
\text { Badan Versi } \\
\text { Audit Report } \\
\text { (PPh Psl. } 15 \\
\text { final) }\end{array}$} & \multirow[t]{2}{*}{$\begin{array}{c}\text { Beban PPh } \\
\text { Badan dgn } \\
\text { Tarif } 25 \%\end{array}$} & \multicolumn{2}{|l|}{ Selisih } \\
\hline & & & & $\mathrm{Rp}$ & $\%$ \\
\hline 1. & $\begin{array}{l}\text { PT. Pelayaran Nasional Bina Buana Raya, } \\
\text { Tbk }\end{array}$ & 5.455 .137 .100 & 35.308 .155 .613 & 29.853.018.513 & 84,55 \\
\hline 2. & PT. Pelayaran Nelly Dwi Putri, Tbk. & 4.470 .808 .458 & 16.087.609.679 & 11.616.801.221 & 72,21 \\
\hline 3. & PT. Logindo SamudraMakmur, Tbk. & 5.444 .674 .160 & 25.551 .082 .098 & 20.106.407.938 & 78,69 \\
\hline 4. & PT. Mitrabahtera Segara Sejati, Tbk. & 16.413 .819 .320 & 92.271 .802 .395 & 75.857 .983 .075 & 82,21 \\
\hline 5. & PT. Wintermar Offshore Marine, Tbk. & 20.017 .248 .120 & 63.062 .653 .580 & 43.045 .405 .460 & 68,26 \\
\hline 6. & PT. Transpower Marine, Tbk. & 5.989 .162 .850 & 21.703 .451 .953 & 15.714.289.103 & 72,40 \\
\hline & Total & 57.790 .850 .008 & 253.984 .755 .316 & 196.193.905.308 & 77,25 \\
\hline
\end{tabular}

Sumber : Laporan Keuangan Yang Diaudit (Audited Financial Statements) Tahun 2012 dan 2013 dari keenam entitas yang terdaftar di Bursa Efek Indonesia

Berdasarkan perhitungan dalam tabel 4-2 tersebut diatas, untuk keenam perusahaan pelayaran yang sudah Tbk tersebut, dapat dikemukakan beberapa hal sebagai berikut :

1. Beban PPh Badan (PPh Psl. 15 final) versi audit report tahun 2012 adalah sebesar Rp. $\quad 57.790 .850 .008$ dibandingkan dengan beban PPh Badan dengan tarif $25 \%$ (global taxation) adalah sebesar Rp. 253.984.755.316. Sedangkan untuk tahun 2013, beban PPh Badan (PPh Psl. 15 final) versi audit report adalah sebesar Rp. 
90.140.909.591 dibandingkan dengan beban PPh Badan dengan tarif 25\% adalah sebesar Rp. 253.984.755.316.

2. Potensi penerimaan negara dari $\mathrm{PPh}$ Badan yang hilang karena penerapan PPh Final tersebut untuk tahun 2012 adalah sebesar Rp. 196.193.905.308 atau $77.25 \%$ dari jumlah pajak yang dapat ditarik bila menggunakan global taxation, sedangkan untuk tahun 2013 adalah sebesar Rp. 272.559.979.554 atau $75.15 \%$ dari jumlah pajak yang dapat ditarik bila menggunakan global taxation.

Penerapan norma perhitungan penghasilan netto atas perusahaan pelayaran berdasarkan pajak penghasilan pasal 15 ( $\mathrm{PPh}$ final) atas perusahaan angkutan laut domestik dan luar negeri di Indonesia ternyata belum memberikan kontribusi penerimaan yang optimal bagi Negara, karena bila dibandingkan dengan penerapan konsep global taxation yang menggunakan Pasal 17 ayat 2a UU PPh 1984, kontribusi bagi penerimaan Negara dari pajak penghasilan badan perusahaan pelayaran lebih rendah. Azas kecukupan Penerimaan atau "The Revenue Adequacy Principle" yang dianggap sebagai azas yang sangat penting di Negara-negara berkembang termasuk Indonesia menjadi terganggu karena cukup signifikannya potensi penerimaan Negara yang hilang yang merupakan selisih antara pajak penghasilan yang terutang menurut global taxation dengan pajak penghasilan yang terutang menurut norma perhitungan penghasilan netto yang tidak bisa direalisir. Pertimbangan dalam pemberian kemudahan dalam administrasi perpajakan malah tidak mampu untuk merespon keutamaan dalam pemenuhan fungsi budgetair sebagai fungsi utama pajak.

\section{Aspek Kaidah Keadilan (equality/equity) Dalam Sistem Pemajakan Perusahaan Pelayaran}

\section{Dengan "Deemed Profit" Untuk Pengenaan PPh Pasal 15 (Final)}

Pasal 15 Undang-Undang PPh Tahun 1984 memberikan mandat kosong kepada Otoritas Perpajakan dalam menghitung besarnya penghasilan dan penghasilan kena pajak bagi golongan Wajib Pajak tertentu, sehingga berdasarkan pertimbangan praktis, oleh Undang-undang ini, Menteri Keuangan diberi wewenang untuk mengeluarkan Keputusan untuk menentukan Norma Penghitungan Khusus guna menghitung besarnya penghasilan netto, yang dengan sendirinya akan menjadi dasar penghitungan penghasilan kena pajak bagi golongan Wajib Pajak tertentu tersebut. Ditinjau dari aspek kaidah keadilan (equality/equity), konsep pemajakan dengan penerapan norma penghitungan khusus dengan pengenaan PPh Pasal 15 (Final) atas perusahaan pelayaran nasional di Indonesia belum memberikan keadilan bagi wajib pajak perusahaan pelayaran yang menderita kerugian fiskal, karena sistem final ini memperhitungkan pajak korporasi berdasarkan peredaran bruto usaha sebagai dasar pengenaan pajak dikalikan dengan tariff final, tidak ada kompensasi kerugian dan tidak pula memperhitungkan biayabiaya usaha. Sebagaimana di stir oleh Mansury, jangan sampai "for the ease of administration" itu dikejar dengan mengorbankan penerapan azas-azas yang harus dipegang teguh, misalnya untuk mengejar kemudahan pemungutan pajak, lalu pengenaan pajak tersebut tidak adil.

Sebagai contoh tiga perusahaan pelayaran berikut ini yakni PT. Tempuran Mas, Tbk., dan PT. Trada Maritime, yang dalam tahun 2012 - 2013 dari paparan laporan keuangan yang diaudit (Audited Financial Statements) mengalami kerugian fiskal namun masih tetap harus bayar $\mathrm{PPh}$ Final, yakni :

- PT. Tempuran Mas, Tbk. dengan rugi fiskal sebesar Rp. 100.063.794.680 di tahun 2011, dan sebesar Rp. 64.651.494.009 di tahun 2012 serta Rp. 
TRANSPARANSI

Jurnal Ilmiah Ilmu Administrasi

ISSN 2085-1162

- 136.082.943.254 (est.) di tahun 2013, namun karena memang sudah ditetapkan bahwa perusahaan pelayaran tersebut dikenakan PPh Pasal 15 yang bersifat final, maka perusahaan ini tetap harus bayar PPh Pasal 15 dari "pendapatan dan beban yang dikenakan pajak final sebesar Rp. 773.151.474.311 di tahun 2012 dan sebesar Rp. 761.605.003.794 di tahun 2012”.

- PT. Trada Maritime, Tbk. yang dalam tahun 2012 dari paparan laporan keuangan yang diaudit (Audited Financial Statements) mengalami kerugian fiskal sebesar Rp. 29.568.899 di tahun 2011 di tahun 2012, namun karena memang sudah ditetapkan bahwa perusahaan pelayaran tersebut dikenakan PPh Pasal 15 yang bersifat final, maka perusahaan ini tetap harus bayar PPh Pasal 15 dari "pendapatan dan beban yang dikenakan pajak final sebesar sebesar Rp. 175.141.635.308 di tahun 2012".

Ibarat peribahasa yang mengatakan "sudah jatuh tertimpa tangga", kondisi semacam inilah yang terjadi pada perusahaan-perusahaan pelayaran di Indonesia yang dalam kegiatan operasionalnya mengalami kerugian, namun tetap bayar pajak penghasilan dan ironisnya kerugian tersebut tidak bisa dikompensasikan ke masa pajak berikutnya.

Sementara itu bila kita bandingkan dengan perusahaan-perusahaan lainnya yang perlakuan perpajakannya mengikuti konsep global taxation, diberlakukan Pasal 6 Ayat (2) UU PPh 1984 yang menegaskan "Jika pengeluaran-pengeluaran yang diperkenankan berdasarkan ketentuan pada ayat (1) setelah dikurangkan dari penghasilan bruto didapat kerugian, kerugian tersebut dikompensasikan dengan penghasilan neto atau laba fiskal selama 5 (lima) tahun berturut-turut dimulai sejak tahun berikutnya sesudah tahun didapatnya kerugian tersebut". Selanjutnya di Pasal 25 ayat (6) UU PPh 1984 menyatakan "Oleh karena itu, berdasarkan ketentuan ini dalam hal-hal tertentu, Direktur Jenderal Pajak diberikan wewenang untuk menyesuaikan perhitungan besarnya angsuran pajak yang harus dibayar sendiri oleh Wajib Pajak dalam tahun berjalan apabila terdapat kompensasi kerugian; Wajib Pajak menerima atau memperoleh penghasilan tidak teratur; atau terjadi perubahan keadaan usaha atau kegiatan Wajib Pajak". Ini salah satu bukti bagaimana konsep global taxation dapat menjadi payung keadilan pajak bagi wajib pajak, dan konsep ini dapat teruji dalam situasi perekonomian bagaimanapun juga tidak akan memperparah kondisi wajib pajak yang lagi mengalami kerugian, serta memberikan batas toleransi yang cukup panjang untuk memperhitungkan/ mengkompensasikan kerugian tersebut hingga lima tahun berikutnya secara berturut-turut.

\section{Perlakuan Pajak Tidak Adil, Karena Tarif Yang "Deemed" Kekecilan, Tidak Sesuai Dengan Syarat Keadilan Horizontal \& Vertikal}

Berikut ini kami petik hasil wawancara peneliti dengan key informan :

1. Bpk. AA. Supardi, Mantan Kepala Kantor Pelayanan Pajak Pontianak dan Kepala Kantor Pelayanan Jakarta Pusat IV serta Kepala Subdit Peraturan Perpajakan Direktorat Jenderal Pajak, yang pernah menjadi salah satu Tim perumus dalam penyusunan UndangUndang Pajak Penghasilan No. 10 Tahun 1994 dan UU KUP No . 9 Tahun 1994, yang juga kini sebagai Dosen Pajak STIAMI, dalam wawancara yang peneliti lakukan, memberikan komentar tentang ketidakadilan pajak dalam penerapan $\mathrm{PPh}$ Pasal 15 yang bersifat final atas pelayaran nasional dengan tariff berdasarkan Norma sebesar 1,2\%, sebagai berikut : 
- Pada dasarnya norma khusus (PPh Pasal 15) dipakai untuk perhitungan pajak yang tidak bisa dihitung secara akuntansi dan PPh Pasal 17 (global taxation) atau tidak bisa berdasarkan pasal $14 \mathrm{UU}$ $\mathrm{PPh}$, seperti halnya dengan perusahaan pelayaran/ penerbangan asing (BUT), dimana pengenaan pajak perseroan/PPh Badan Pasal 17 sulit diterapkan secara murni. Misalnya kesulitan dalam perhitungan biaya penyusutan kapal atau pesawat untuk dapat dialokasikan sebagai biaya BUT padahal domisili kapal atau pesawat tersebut terdaftar di kantor pusatnya di luar negeri. Begitu juga dengan masalah dalam alokasi biaya gaji dan overhead crew kapal/pesawat, dan pegawai administrasi head office serta expatriate yang bekerja di kantor representatif BUT perusahaan pelayaran/penerbangan asing, biaya operasional/eksploitasi kapal yang perhitungannya cukup kompleks. Ditambah lagi bila Negara tempat domisili perusahaan pelayaran atau penerbangan asing (BUT) tersebut memiliki Tax Treaty dengan Negara Indonesia, dimana tariff dividend yang ditetapkan dalam Tax Treaty tersebut lebih rendah dari tariff PPh Pasal 26. Sudah tariff $\mathrm{PPh}$ Pasal 15 nya rendah $(2,64 \%)$, tariff dividend-nya juga rendah.Tentu saja ini menjadi tidak adil.

- Norma khusus (PPh Pasal 15) tidak memperhatikan tariff progresivitas yang mencerminkan asas ability to pay. Bila perbandingan hasil perhitungan antara besarnya $\mathrm{PPh}$ Badan dengan tariff PPh Pasal 17 dengan tariff PPh Pasal 15 untuk perusahaan pelayaran nasional menunjukkan selisih (lebih besar dengan tariff PPh Pasal 17) yang signifikan, maka tentu hal ini tidak adil, padahal untuk Wajib Pajak Badan lainnya sudah menerapkan global taxation yang memberikan hak untuk melakukan kompensasi kerugian bagi Wajib Pajak yang menderita kerugian fiskal dalam tahun yang bersangkutan.

- Pada prinsipnya saya setuju dikenakan tariff untuk perusahaan pelayaran nasional yang bervariatif (sebagai pengganti tariff $\mathrm{PPh} \mathrm{PPh}$ Pasal 15 yang $1,2 \%$ bagi perusahaan pelayaran domestik dan $2,64 \%$ bagi perusahaan pelayaran asing tersebut) sebagaimana halnya dengan usaha jasa konstruksi yang dikenakan PPh Pasal 4(2) yang bersifat Final dengan tariff yang bervariatif ( $2 \%$ sampai dengan $6 \%)$. Untuk keadilan pajak harus diperhatikan tariff pajak yang adil dengan memperhatikan tingkat keuntungan pengusaha kecil dan besar dan juga memperhatikan perubahan ketentuan perundangundangan perpajakan yang berlaku. Jadi untuk mengetahui laba neto yang wajar sebagai dasar pengenaan pajak yang baik dibutuhkan penelitian yang mendalam, dan tidak cukup hanya dengan pertemuan dengan pihak asosiasi perusahaan pelayaran (INSA). Dalam kaitan ini harus juga dipertimbangkan penjelasan Pasal 14 ayat(1), bahwa Norma Penghitungan disusun sedemikian rupa berdasarkan hasil penelitian atau data lain, dan dengan memperhatikan kewajaran. Norma Penghitungan akan sangat membantu Wajib Pajak yang belum mampu menyelenggarakan pembukuan untuk menghitung penghasilan neto.

2. Bpk. Ishak Tongkudu, Konsultan Pajak IT\&Partner, Mantan Kepala Kantor Pelayanan Pajak Kramat Jati, Cawang, Jakarta Timur, dalam wawancara yang 
TRANSPARANSI

Jurnal Ilmiah Ilmu Administrasi

ISSN 2085-1162

peneliti lakukan, memberikan komentar tentang ketidakadilan pajak dalam penerapan PPh Pasal 15 yang bersifat final atas pelayaran nasional dengan tariff berdasarkan Norma atau"deemed profit" sebesar 1,2\%, sebagai berikut :

- Modus pengenaan pajak final karena simple, mudah administrasinya dan hasilnya pasti.

- Penetapan "deemed profit"yang kekecilan akan justru mencerminkan ketidakadilan karena tidak equal treatment.

- Penetapan "deemed profit"yang besar juga tidak adil. Sebenarnya pengenaan "deemed profit" dengan tariff $1,2 \%$ tersebut dimaksudkan untuk merangsang perusahaan pelayaran memajukan pelayaran domestik/interinsuler melayani trayek pelayaran ke wilayah timur (misalnya Papua) dengan pertimbangan ketika pulangnya ke pelabuhan muat asal (Jakarta) muatan balik kapalnya kosong sehingga cost angkutannya menjadi tinggi. Ketika itu armada pelayaran ke wilayah timur masih kurang, karena itu perusahaan pelayaran interinsuler harus ditolong dan dilindungi serta diberikan keringanan dalam beban pajaknya. Sampai sekarang kondisi pelayaran domestik/interinsuler ke wilayah timur belum banyak mengalami perubahan. Jadi kita bisa melihat dalam kebijakan penetapan "deemed profit" tersebut ada fungsi regulerend didalamnya, bagaimana supaya pengusaha terangsang untuk mau mengembangkan usahanya ke wilayah timur, serta untuk melindungi perusahaan pelayaran domestik/interinsuler supaya kelangsungan hidup usahanya dapat berkesinambungan.
Volume VIII, Nomor 02, September 2016

- Pada prinsipnya saya setuju dikenakan tariff untuk perusahaan pelayaran interinsuler yang bervariatif (sebagai pengganti tariff $\mathrm{PPh} \mathrm{PPh}$ Pasal 15 yang 1,2\% tersebut) sebagaimana halnya dengan usaha jasa konstruksi yang dikenakan PPh Pasal 4(2) yang bersifat Final dengan tariff yang bervariatif (2\% sampai dengan $6 \%$ ).

- Walaupun demikian, kita tidak bisa berpaku pada kondisi yang dulu karena sudah lebih dari 20 tahun berselang. Oleh sebab itu harus ada penelitian yang mendalam tentang penetapan"deemed profit"tersebut sejauh mana kondisi dulu masih relevan dibandingkan dengan yang kondisi sekarang, dan tidak cukup hanya dengan pertemuan dengan pihak asosiasi perusahaan pelayaran (INSA) saja.

Penulis menyimpulkan pendapat dari kedua pakar perpajakan tersebut diatas yang mereka itu adalah Mantan Kepala Kantor Pelayanan Pajak tentang ketidakadilan dalam penerapan $\mathrm{PPh}$ Pasal 15 yang berdasarkan norma khusus/norma penghitungan penghasilan neto untuk perusahaan nasional pelayaran Indonesia, adalah tidak jauh berbeda, bahwa "deemed profit" yang kekecilan (dalam arti terdapat perbedaan positif yang mencolok/signifikan antar besarnya $\mathrm{PPh}$ Badan yang dihitung berdasarkan Norma khusus PPh Pasal 15 dengan yang dihitung berdasarkan PPh Pasal 17) mencerminkan ketidakadilan pajak, dan oleh sebab itu dibutuhkan penelitian yang mendalam (selain melakukan pertemuan musyawarah untuk mencapai kesepakatan dengan pihak asosiasi perusahaan pelayaran-INSA) untuk menetapkan tariff yang wajar/adil sehingga penerimaan negara dari sektor usaha pelayaran nasional ini dapat memberikan kontribusi yang optimal sebagai salah satu sumber pembiayaan 
Negara yang dapat diandalkan di masa mendatang.

Sudah waktunya pemerintah cq. Direktorat Jenderal Pajak meninjau ulang sistem pemajakan atas perusahaan pelayaran baik untuk angkutan domestik maupun angkutan luar negeri, sehingga dapat diharapkan sektor pelayaran nasional ini dapat memberikan kontribusi yang optimal bagi penerimaan Negara. Penetapan norma khusus bagi perusahaan pelayaran asing (BUT) mungkin masih dapat dipertimbangkan mengingat cukup kompleksnya atau mengalami kesulitan dalam perhitungan biaya-biaya perusahaan pelayaran tersebut termasuk penyusutan kapal dan kru kapal serta pegawai administrasi head office dan expatriate untuk dapat dialokasikan sebagai biaya BUT. Tidak ada suatu urgensi dan kompleksitas yang tinggi (seperti halnya dengan trend transaksi di Bursa Efek Indonesia) yang mengharuskan perusahaan pelayaran untuk difinalkan $\mathrm{PPh}$ badannya karena frekuensi transaksi masih dalam batas kegiatan normal usaha yang masih bisa dikontrol melalui perjanjian pengangkutan laut dan dokumen-dokumen pengangkutan (shipping documents) yang ada. Begitupula asset yang dimiliki serta pegawainya juga berdomisili di Indonesia.

Berbeda dengan transaksi di Bursa Efek Indonesia yang melayani transaksi jual beli efek di pasar sekunder, volatilitasnya (merupakan pengukuran statistik untuk fluktuasi harga suatu sekuritas atau komoditas selama periode tertentu) serta turnover dan frekuensi transaksi pergerakan saham demikian tinggi di Pasar Modal Indonesia, trend-nya meningkat (kemungkinan terjadi panic selling) bilamana pergerakan Indeks Harga Saham Gabungan (IHSG) sedang menurun (bearish) maka terjadi panic selling, namun apabila IHSG bergerak sebaliknya panic buying tidak terjadi. Panic selling diartikan sebagai kondisi dimana terjadi penjualan saham dalam volume besar di pasar. Untuk Pasar Modal di Indonesia investor lebih sensitif terhadap faktor- faktor negatif yang mempengaruhi pergerakan saham, sehingga seringkali terjadi panic selling dibandingkan dengan berita positif dalam mempengaruhi indeks. (Baca juga Laporan Tim Studi Volatilitas Pasar Modal Indonesia Dan Perekonomian Dunia, Kementerian Keuangan, tahun 2011). Dalam kondisi perkembangan pasar modal yang sensitif demikian itu, maka dapat dipahami bila pengenaan Pajak Final atas penjualan efek oleh pialang di Bursa Efek Indonesia lebih efektif daripada cara pengenaan pajak dengan Pasal 17 ayat 2a UU PPh 1984 (global taxation).

Bagaimanapun juga untuk memberikan penguatan dalam gagasan/visi dalam mewujudkan Indonesia sebagai poros maritim dunia (sebagaimana beritanya diangkat oleh TEMPO.CO, Jakarta tertanggal 22 April 2015 tentang Presiden Joko Widodo memaparkan visi kelautan dalam Konferensi Tingkat Tinggi Negara-negara Asia Timur (KTT EAS) di Myanmar, Kamis, 13 November 2014, Indonesia), dari lima pilar utama yang diagendakan dalam pembangunan, Jokowi menuturkan, Pertama, membangun kembali budaya maritim Indonesia. "Sebagai negara yang terdiri atas 17 ribu pulau, bangsa Indonesia harus menyadari bahwa identitas, kemakmuran, dan masa depannya sangat ditentukan oleh pengelolaan samudra," (Baca: Jokowi Yakin Indonesia Jadi Poros Maritim Dunia), maka dalam kaitan ini sangat dipandang perlu bagi pemerintah cq. Departemen Keuangan untuk membenahi pengelolaan perpajakan pelayaran nasional/samudera ini agar dapat memberikan kontribusi yang optimal bagi penerimaan Negara, selain memberikan rasa penegakan keadilan bagi seluruh rakyat Indonesia.

\section{SIMPULAN DAN SARAN Simpulan}

Dari analisis dan pembahasan pada bab-bab terdahulu, penulis menyimpulkan sebagai berikut : 
TRANSPARANSI

Jurnal Ilmiah Ilmu Administrasi

ISSN 2085-1162

1. Penerapan norma perhitungan penghasilan netto atas perusahaan pelayaran berdasarkan pajak penghasilan pasal 15 ( $\mathrm{PPh}$ final) atas perusahaan angkutan laut domestik dan luar negeri di Indonesia ternyata belum memberikan kontribusi penerimaan yang optimal bagi Negara, karena bila dibandingkan dengan penerapan konsep global taxation yang menggunakan Pasal 17 ayat 2a UU PPh 1984, kontribusi bagi penerimaan Negara dari pajak penghasilan badan perusahaan pelayaran lebih rendah. Azas kecukupan Penerimaan atau "The Revenue Adequacy Principle” yang dianggap sebagai azas yang sangat penting di Negara-negara berkembang termasuk Indonesia menjadi terganggu karena cukup signifikannya potensi penerimaan Negara yang hilang yang merupakan selisih antara pajak penghasilan yang terutang menurut global taxation dengan pajak penghasilan yang terutang menurut norma perhitungan penghasilan netto yang tidak bisa direalisir. Pertimbangan dalam pemberian kemudahan dalam administrasi perpajakan dengan mengedepankan prinsip the ease administration and compliance (kemudahan administrasi dan kepatuhan wajib pajak) malah tidak mampu untuk merespon keutamaan dalam pemenuhan fungsi budgetair sebagai fungsi utama pajak.

2. Ditinjau dari aspek kaidah keadilan pajak (equality/equity), konsep pemajakan dengan pengenaan $\mathrm{PPh}$ Pasal 15 (Final) atas perusahaan pelayaran di Indonesia mencerminkan ketidakadilan pajak, yang dapat dilihat dari "deemed profit" yang kekecilan (dalam arti terdapat perbedaan positif yang mencolok/signifikan antara besarnya PPh Badan yang dihitung berdasarkan Norma khusus PPh Pasal 15 dengan yang dihitung berdasarkan PPh Pasal 17). Selain itu, bagi wajib pajak perusahaan pelayaran yang menderita kerugian fiskal kondisi finansilnya akan semakin terpuruk, karena sistem final ini memperhitungkan pajak korporasi berdasarkan peredaran bruto usaha sebagai dasar pengenaan pajak dikalikan dengan tariff final, tidak ada kompensasi kerugian dan tidak pula memperhitungkan biaya-biaya usaha.

\section{Saran}

Berdasarkan simpulan tersebut diatas, penulis menyarankan agar pemerintah cq. Direktorat Jenderal Pajak mereviu sistem pemajakan atas perusahaan pelayaran nasional baik untuk angkutan domestik maupun angkutan luar negeri, dan oleh sebab itu dibutuhkan penelitian yang mendalam (selain melakukan pertemuan musyawarah untuk mencapai kesepakatan dengan pihak asosiasi perusahaan pelayaranINSA) untuk menetapkan tariff yang wajar/adil sehingga penerimaan negara dari sektor usaha pelayaran nasional ini dapat diharapkan memberikan kontribusi yang optimal sebagai salah satu sumber pembiayaan Negara yang dapat diandalkan di masa mendatang. Kalau masih bisa pemajakannya dengan menerapkan konsep global taxation yang jelas-jelas tidak perlu diargumentasikan lagi tentang konten kaidah keadilannya kenapa harus menggunakan norma khusus?

\section{DAFTAR PUSTAKA}

Alsah, Syarifuddin. 2002. Pemotongan Pemungutan Pajak Penghasilan (Withholding Tax). 
Jakarta : Penerbit Kharisma.

Amir M.S. 1997. Peti Kemas, Masalah dan Aplikasinya. Jakarta: PT. Pustaka Binaman

Pressindo.

Anwar Pohan, Chairil. 2012. Optimizing Corporate Tax Management-Kajian Perpajakan dan

Tax Planning-nya Terkini. Jakarta : Bumi Aksara.

2014. Manajemen

Perpajakan- Strategi Perencanaan Pajak dan Bisnis. Edisi

Redua/Revisi . Jakarta : Gramedia Pustaka Utama.

2014. Pembahasan

Komprehensif Pengantar Perpajakan,

Teori dan Konsep

Hukum Pajak. Jakarta : Mitra

Wacana Media.

2014. Pembahasan

Komprehensif Perpajakan Indonesia, Teori dan Kasus.

Jakarta : Mitra Wacana Media.

Asri Harahap, Abdul. 2004. Paradigma

Baru Perpajakan Indonesia. Jakarta :

Integrita

Dinamika Press.

Barata Atep Adya dan H.M. Jajat

Djuhadiat. 2004. Pemotongan-Pemungutan

Pajak Penghasilan Dan Kredit

Pajak Luar Negeri. Jakarta : PT. Elex

Media Komputindo.

Brotodihardjo Santoso.R. 1995. Pengantar

Ilmu Hukum Pajak, edisi ke-3: Eresco

Bandung.

Burton, Richard. 2014. Kajian Perpajakan

Dalam Konteks Kesejahteraan dan

Keadilan.

Jakarta: Mitra Wacana Media.

Edward F Steven. 1975. Shipping Practice,

$9^{\text {th }}$ edition : Pitman Publishing.

D. Larry CPA. Jack P.Friedman, Susan B.

Anders.1994. Dictionary of Tax Terms:

Barron's.

Gunadi, 2013 . Panduan Komprehensif

Pajak Penghasilan. edisi 2013. Jakarta :

Penerbit Bee

Media Indonesia.

Faisal, Gatot S.M. 2009. How To Be A

Smarter Tax Payer. Jakarta: Grasindo.
Haula Rosdiana dan Edi Slamet Irianto.2012. Pengantar Ilmu Pajak, Kebijakan dan

Implementasinya di Indonesia.

Jakarta : Rajawali Press.

Hamonangan Simanjuntak,Timbul dan Imam Mukhlis. 2012. Dimensi Ekonomi Perpajakan

Dalam Pembangunan Ekonomi.

Depok :Raih Asa Sukses (Penebar Swadaya Group).

Ikatan Akuntan Indonesia. 2009. Standard Akuntansi Keuangan Per 1 Juli 2009. Jakarta:

Salemba Empat.

Istopo. 1992. Unimoda dan Multimodal Transport, Angkutan Barang Terpadu Darat, Laut dan

Udara. Jakarta :Yayasan INFFA (Indonesia Freight Forwarder's Foundation).

Kosasih, Engkos dan Hananto Soewedo. 2012. Manajemen Perusahaan Pelayaran. Jakarta:

PT. Radjagrafindo Persada.

Mansury, R. 1992. Indonesian Income Tax : A Case Study in Tax Reform of a Developing

Country. Singapore :Asian Pasific Tax and Investment Research Centre. .1996. Pajak Penghasilan

Lanjutan . Jakarta: Ind Hill Co. 1994 \& 1996. Panduan Konsep Utama Pajak Penghasilan Indonesia Jilid 1-III.

Jakarta :PT. Bina Rena Pariwara. . 2000. Pembahasan Mendalam

Pajak Atas Penghasilan. Jakarta : Yayasan

Pengembangan dan penyebaran Pengetahuan Perpajakan (YP4)

Martono, H.K. dan Eka Budi Tjahyono.2011. Transportasi Di Perairan Berdasarkan Undang-

Undang Nomor 17 Tahun 2008. Jakarta : Rajawali Pers.

Muchtar. 2013. Metode Praktis Penelitian Deskriptif Kualitatif. Jakarta :Penerbit Referensi. 
TRANSPARANSI

Jurnal Ilmiah Ilmu Administrasi

ISSN 2085-1162

Musgrave, Richard A dan Peggy B. Musgrave. 1989. Public Finance in Theory and Practice.

1989. New York : Mcgraw Hill Inc.Edisi kelima. (diterjemahkan oleh Ellen Gunawan dan Rudi Sitompul). Jakarta : Penerbit Erlangga.

Nazir. Moh. 1988. Metode Penelitian. Jakarta:Ghalia Indonesia.

Neuman, W.Lawrence. 2006. Social Research Methods: Qualitative and Quantitative

Research. USA: University of Wisconsin. Hal 188-198.

Nurmantu, Safri. 2005. Pengantar Perpajakan, edisi 3 . Jakarta : Granit.

Purwosutjipto H.M.N. 1989. Pengertian Hukum Dagang Indonesia. Cetakan ketiga. Jakarta:

Penerbit Djambatan.

Rosdiana Haula dan Edi Slamet Irianto. 2012. Pengantar Pajak. Jakarta : Rajawali Press.

Smith, Adam. 1981. An Inquiry into the Nature and Causes of the Wealth of Nations.

Indianapolis : Liberty Classics.

Sugiyono. 2010. Memahami Penelitian

Kualitatif. Bandung : Penerbit Afabeta.

Suparmoko. 2014. Keuangan Negara Dalam Teori dan Praktik, edisi 6. Yogyakarta :BPFE

Suyono, R.P. 2005. Shipping, Pengangkutan Intermodal Ekspor Impor Melalui Laut. Edisi
Volume VIII, Nomor 02, September 2016

keempat. Jakarta: Penerbit PPM

Tansuria, Billy Ivan. 2011. Pajak Penghasilan Final. Yogyakarta : Graha Ilmu.

\section{Sumber Lain :}

Kementerian Keuangan RI. 2011. Tim Studi Volatilitas Pasar Modal Indonesia Dan

Perekonomian Dunia. Badan Pengawas Pasar Modal Dan Lembaga Keuangan. "Laporan Studi Volatilitas Pasar Modal Indonesia tahun 2011".

Republik Indonesia. "Undang-undang Nomor 6 Tahun 1983 tentang Ketentuan Umum dan Tata Cara Perpajakan sebagaimana telah beberapa kali diubah terakhir dengan Undang-undang Nomor 16 Tahun 2009".

Republik Indonesia. 'Undang-Undang Nomor 7 Tahun 1983 tentang Pajak Penghasilan sebagaimana telah beberapa kali diubah terakhir dengan Undang- Undang Nomor 36 Tahun 2008".

Republik Indonesia. "Undang-Undang Nomor 8 Tahun 1983 tentang Pajak Pertambahan Nilai sebagaimana telah beberapa kali diubah terakhir dengan Undang- Undang Nomor 42 Tahun 2009”. 